\title{
GRANTS FOR ASIAN POLITICAL SCIENTISTS
}

The American Political Science Association again has received from The Asia Foundation a grant for encouraging closer relations between Asian and American political scientists. The funds will be used in three ways:

1) To enable Asian political scientists to become members of The American Political Science Association for a one-year period at greatly reduced rates. Membership includes subscription to The American Political Science Review. To be eligible, applicants must reside in one of the Asian countries listed below.

2) To enable libraries, university departments, and research institutes in Asia, who have heretofore been unable to do so, to subscribe to The American Political Science Review at greatly reduced rates.

3) To supplement travel expenses of Asian political scientists who are in the United States and who wish to attend meetings of The American Political Science Association. The next meeting will be held September 5-9, in the Pick-Congress Hotel, Chicago.

(Applicants must be at least at the graduate student level and may come from any of the following Asian countries: Afghanistan, Burma, Ceylon, Hong Kong, India, Indonesia, Japan, Korea, Laos, Malaysia, Nepal, Pakistan, the Philippines, the Ruyukyus, the Republic of China (Taiwan), Thailand, and Vietnam. Applicants who have not previously received grants will be given first consideration. Application forms may be obtained from The American Political Science Association, 1527 New Hampshire Ave., N.W., Washington, D. C. 20036.)

\section{BIOGRAPHICAL DIRECTORY AVAILABLE AT REDUCED RATES}

A limited supply of the fourth edition of the Biographical Directory, published in 1961 , is available for $\$ 1.25$ per copy for the paperbound copy and $\$ 2.25$ per copy for the clothbound copy. Formerly, the price was $\$ 12.50$ for the clothbound and $\$ 10.00$ for the paperbound. Orders should be sent to:

The American Political Science Association 1527 New Hampshire Avenue, N. W.

Washington, D. C. 20036 


\section{in the study of politics}

New research areas open new approaches to government through exploration of new concepts and theories.

For research-based books that are carefully integrated with existing

literature:

Rand McNally books in political science.

\section{AMERICAN POLITICS RESEARCH SERIES}

Edited by AARON WILDAVSKY

University of California, Berkeley

Each book in the series consists of an original research venture tied into existing information and theory in such a way as to make a new contribution to the field.

POWER IN COMMITTEES: An Experiment in the Governmental Process JAMES DAVID BARBER - Yale University $1966 \cdot 189$ pages $\cdot \$ 5.00$

\section{SOCIAL INSECURITY: The Politics of Welfare}

GILBERT Y. STEINER - The Brookings Institution $1966 \cdot 270$ pages $\cdot \$ 6.00$

POLITICS, ECONOMICS, AND THE PUBLIC:

Policy Outcomes in the American States

THOMAS R. DYE - University of Georgia

$1966 \cdot 325$ pages $\cdot \$ 6.00$

\section{AMBITION AND POLITICS:}

Political Careers in the United States

JOSEPH A, SCHLESINGER. - Michigari State University

$1966 \cdot 226$ pages $\cdot \$ 6.00$

\section{STUDIES IN POLITICAL CHANGE}

Edited bY MYRON WEINER

Massachusetts Institute of Technology

Aspects of political change in developing nations are illustrated through specific examples of change and combined with a theoretical understanding of the processes of such change.

CREATING POLITICAL ORDER: The Party-States of West Africa

ARISTIDE R. ZOLBERG - University of Chicago $1966 \cdot 168$ pages $\cdot \$ 2.50$ paper

SONS OF THE ESTABLISHMENT:

Elite Youth in Panama and Costa Rica

DANIEL GOLDRICH • University of Oregon

1966 - 139 pages $-\$ 2.50$ paper

PUBLIC LIBERTIES IN THE NEW STATES

DAVID H. BAYLEY • University of Denver

$1964 \cdot 152$ pages $\cdot \$ 2.50$ paper

RAND MCNALLY \& COMPANY The College Department - Chicago, Illinois 60680 


\section{the study \\ of international}

politics

A demanding. interdisciplinary study calls for currency, accuracy. and competent analysis.

Whether you are concerned with the laws of nations, aspects of human behavior, or the prospects for peace. look to the books in political science from

Rand McNally.
INTERNATIONAL REGIONS

AND THE INTERNATIONAL SYSTEM:

\section{A Study in Political Ecology}

BRUCE M. RUSSETT - Yale University

New 1967

Explores some of the relationships between political systems and their social/physical environments in order to group political units into larger clusters. Comparisons are made at two times: the early 1950's and the early 1960's. They are based on five criteria : socio-cultural similarity, similarity of political behavior in international politics, political interdependence, economic interdependence, and geographic proximity. No other book has as rigorous quantitative analysis and hard evidence applied to these theoretical interests at the global level.

THE FUNCTIONS OF INTERNATIONAL LAW: An Introduction to the Role of International Law in the Contemporary World

WILLIAM D. COPLIN - Wayne State University 1966 - 312 pages - $\$ 3.50$ paper

Discusses contemporary operation of international law through an interdisciplinary approach and in terms of social science concepts. Outlines the means by which international law and organization contribute to the development of an international political culture. Appendices contain seven examples of treaties and other documents of international law.

\section{HUMAN BEHAVIOR AND INTERNATIONAL POLITICS:} Contributions from the Social-Psychological Sciences

Edited by J. DAVID SINGER - University of Michigan $1965 \cdot 466$ pages $\quad \$ 9.00$

Nearly fifty articles by prominent sociologists and psychologists are carefully edited and condensed to point up the connection between behavioral sciences and international relations. Organized in terms of one theoretical approach to comparative foreign policy.

\section{TOWARD A STRATEGY OF PEACE}

Edited by WALTER C. CLEMENS, JR. Massachusetts Institute of Technology 1965 - 264 pages - \$3.50 paper

The obstacles to peace-as well as the approaches to a strategy of peace-are examined by more than a dozen scholars and public officials. The selections show interrelationships of domestic and international affairs.

RAND MCNALLY \& COMPANY The College Department • Chicago, Illinois 60680 


\section{The Nature and Function of International Organization Second Edition}

\section{By STEPheN S. Goodspeed, University of California, Santa Barbara}

In a completely revised and updated study, Professor Goodspeed draws an objective picture of international organization, past and present. New material in the Second Edition includes an analysis of the most recent developments affecting colonialism, full coverage of all cases and advisory opinions of the International Court of Justice, and a survey of the financial problems of the United Nations from 1960.

$1967 \quad 736 \mathrm{pp}$. illus.

$\$ 7.50$

\section{Freedom and the Court:}

\section{Civil Rights and Liberties in the United States}

\section{By Henry J. Abraham, University of Pennsylvania}

The study examines the role of the judiciary in the United States from 1789 to the present in determining the evolution and implementation of certain fundamental civil rights. Its central purpose is to consider the lines a democratic society must draw between the rights of the individual and the rights of the community as a whole.

April 1967

$352 \mathrm{pp}$.

cloth $\$ 7.50$

paper $\$ 2.75$

\section{The Politics of the Third World}

\section{By J. D. B. MILLER, Australian National University}

The study examines those countries of the Afro-Asian bloc united by the common attributes of being non-European, non-Communist, and poor. Professor Miller is primarily concerned with international behavior of the Third World states and devotes particular attention to those aspects of their domestic affairs that contribute towards foreign policy. The general conclusion of the study is that Third World unity as a distinctive political force has not been achieved and that harmony of view within the Third World exists only on issues of symbolic importance such as colonialism and economic development.

$1967 \quad 144 \mathrm{pp}$ cloth $\$ 3.75$

paper $\$ 1.50$

\section{Modern Capitalism:}

\section{The Changing Balance of Public and Private Power}

By ANDRew Shonfield, Royal Institute of International Affairs

"Perhaps the most important book of the last decade, Mr. Shonfield achieves the difficult task of making sense out of present day politics and economics of the Western World."-Henry W. Morton, Queens College, New York

$1966475 \mathrm{pp}$.

cloth $\$ 10.50$

paper $\$ 4.50$

\section{Contemporary French Political Thought}

\section{By RoY Prence, University of Michigan}

"A pioneering work which opens a number of avenues for exploration by American political scientists. Basic to any course in comparative political theory dealing with contemporary problems."-H. Malcolm Macdonald, University of Texas

1966 $288 \mathrm{pp}$. cloth $\$ 5.75$

paper $\$ 2.50$ 


\section{The New States of Asia: A Political Analysis}

\section{By Michael Brecher, McGill University}

Recent events in Southern Asia and their relevance for all peoples are described in these six political essays. Following an introductory chapter, Professor Brecher discusses the colonial epoch, the quest for internal political stability, the role of Israel in the Afro-Asian community, and the often misunderstood non-alignment policy. At the heart of the study is an analysis of the theory of subordinate state systems.

\section{South-East Asia: Race, Culture, and Nation}

By GUY HunTer, Institute of Race Relations, London

Professor Hunter investigates the experience of the nations of South-East Asia as they attempt to weld many diverse peoples and cultures into unified, modern nations. Following a historical and geographical survey of the area of his study, he turns to aspects affecting the social and economic life of the region. Within the context of the nationalism of developing countries, the study indicates the global relevance of the Asian nations' experience.

$1966 \quad 208 \mathrm{pp}$. $\quad 16$ tables $\quad$ cloth $\$ 4.50 \quad$ paper $\$ 1.95$

\section{Three Worlds of Development:}

The Theory and Practice of International

Stratification

By IRVING Lours Honowitz, Washington University

One of the clearest and most carefully documented studies of the underlying crises of development I have seen."-D. E. Ashford, Cornell University

$1966 \quad 528 \mathrm{pp}$ cloth $\$ 8.50$

paper $\$ 2.95$

\section{The Springtime of Freedom:}

\section{Evolution of Developing Societies}

By William McCord, Rice University

\section{Readings in American Democracy Second Edition}

Edited by Gerald Stourzh and Ralph Lerner. Revised by H. C. Harian, Chicago City Junior College 


\section{The Democratic Givilization}

By Lesure LIPSon, University of California at Berkeley 1964 $632 \mathrm{pp}$.

\section{Elements of Democratic Government Fourth Edition}

By J. A. Corry, Queen's University, and Henry J. ABraham, University of Pennsylvania

1964

$842 \mathrm{pp}$.

\section{Free Government in the Making:}

Readings in American Political Thought

Third Edition

By Alpheus T. Mason, Princeton University

1965

$952 \mathrm{pp}$.

$\$ 8.00$

\section{Readings in Economics and Politics}

\section{Second Edition}

Edited by H. C. HaRLaN, Chicago City Junior College

1966

$800 \mathrm{pp}$.

paper $\$ 2.75$

\section{Equality in America: Religion, Race, and the Urban Majority}

By Alan P. Grimes, Michigan State University

1964

144 pp.

cloth $\$ 4.00$

paper $\$ 1.50$

\section{The Judicial Process:}

An Introductory Analysis of the Courts of the United

States, England, and France

By Henry J. Abraham, University of Pennsylvania

\section{Men at the Top: A Study in Community Power}

By Robert Presthus, University of Oregon

1964

496 pp.

cloth $\$ 8.50$

paper $\$ 2.95$

Oxford University Press / 200 Madison Ave. / N.Y., N.Y. 10016 


\section{Oxford Unimersity Prest 1840-1966}

By W. B. SUTCH. The first third of this book was originally published in 1942 and established itself as a pioneer and key work on New Zealand history. Now the original volume serves as an introduction to the social history of the last thirty years. The author was close to the policymakers throughout these years and gives a vivid account of the various measures and achievements of the first Labour government, the post-war conflicts, the Holmes case, legislation that diminished civil liberties, the influences of U.S. foreign policy, and the country's failure to build a balanced economy.

Cloth, $\$ 10.40 ;$ paper, $\$ 4.40$

\section{Australia, Britain and E.E.C.}

By H. G. Gelber, Monash University, Melbourne. Reactions to Britain's desire to apply for membership in the European Economic Community were many and varied, in Britain itself, in Europe, and throughout the Commonwealth. In this book the author has put into world perspective Australia's position and attitudes, from the time of the first tentative discussion to the final breakdown of the Brussels talks. It is against the background of the evolving situation in Europe and the political preoccupations of Mr. Macmillan that the factors affecting Australia are discussed in detail.

$\$ 9.60$

\section{The NATO International Staff / Secretariat 1952-1957}

\section{A Study in International Administration}

By RoBert S. Jordan, George $W$ ashington University. This book examines three connected themes of international importance: the origin and powers of the office of SecretaryGeneral of NATO from its foundation in 1952 to 1957; the establishment, growth, and function of the International Staff/Secretariat in the same period; and, as a major influence on the development of both, the professional background, personality, and ideas of Lord Ismay, the First Secretary-General. The information is closely documented, and much of it is published here for the first time.

$\$ 9.60$

\section{The Revolution in Egypt's Economic System}

\section{From Private Enterprise to Socialism, $1952-1965$}

By Patrick O'Brien, School of Oriental and African Studies, University of London. The transformation in Egypt's economic organization is traced, explained, and evaluated in its historical sequence. Various facets of the subject are studied, including investments and savings, industrialization, agriculture, consumption, and the role of ideology. Central to the analysis is the explanation for the profound and rapid changes in Egypt, which can add to our understanding of the widespread rejection of private enterprise by other nationalist régimes in Asia and Africa. 2 tables. (Royal Institute of International Affairs.) $\$ \$ 80$ 


\section{American}

Government and Politics

\section{A Reader}

1967

400 pages

$\$ 4.25$

William J. Moore, Walter C. Schuling, Aram M. Sogomonian, and George K. Zaharopoulos, San Bernardino Valley College

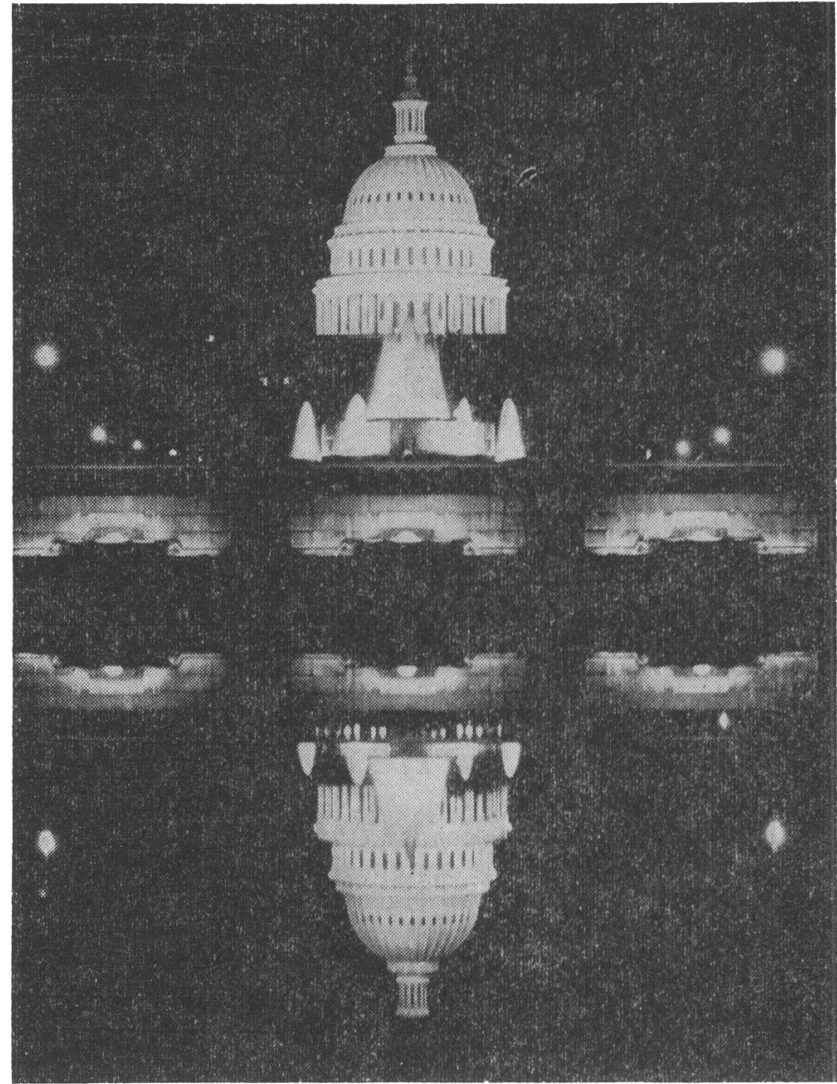

CHAPTER HEADINGS AND AUTHORS REPRESENTED

\section{Government and Politics: A Prologue}

Aristotle, Montesquieu, Robert Maclver, Benito Mussolini, Joseph Stalin, J. William Fulbright, Charles Frankel.

The American Constitutional System

James Madison, Clinton Rossiter, Martin Diamond, Russell Kirk, Sidney Hook, States' Rights Party Platform of 1948, Orville Freeman, Walter Millis.

The Courts

Tom C. Clark, William O. Douglas, Marbury $v$. Madison, Irving R. Kaufman, Thurgood Marshall.

\section{Political Behavior and Party Politics}

Clinton Rossiter, Campbell-Converse-MillerStokes, Henry A. Turner, Berelson-LazarsfeldMcPhee, Roper-Gallup-McDonald, Adlai E. Stevenson.

\section{The Congress}

Lewis Anthony Dexter, Clem Miller, Hubert $\mathrm{H}$. Humphrey, Tom Wicker, Douglas M. Davis.
The President

Sidney Hyman, Louis W. Koenig, John F. Kennedy, Theodore C. Sorensen, Arthur M. Schlesinger.

The Government and the People

Stuart Chase, Barry Goldwater, Frank Church, Paul H. Douglas, Harlan Cleveland, Brown v. Board of Education, Burke Marshall, Lyndon B. Johnson.

\section{The United States and the World}

George W. Ball, Hans J. Morgenthau, George F. Kennan, J. William Fulbright, Dean Rusk, Stuart Chase, C. P. Fitzgerald, George C. Lodge, Robert L. Heilbroner.

State and Local Government

LeRoy Collins, William B. Munro, Constitution of the State of California, Reynolds $v$. Sims, Andrew Hacker, Newsweek, The American Assembly, Donald J. Curran.

\section{Contemporary Challenges}

Richard F. Hamilton, Robert M. Hutchins, Robert L. Heilbroner.

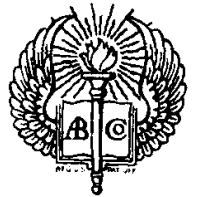

College Division

\section{American Book Company}

\section{Fifth Avenue, New York, New York 10003}

Please mention Thr American Politicat. ScIence Review when writing to advertisers 


\section{"A monumental conception"" \\ "Raymond Aron's masterpiece""}

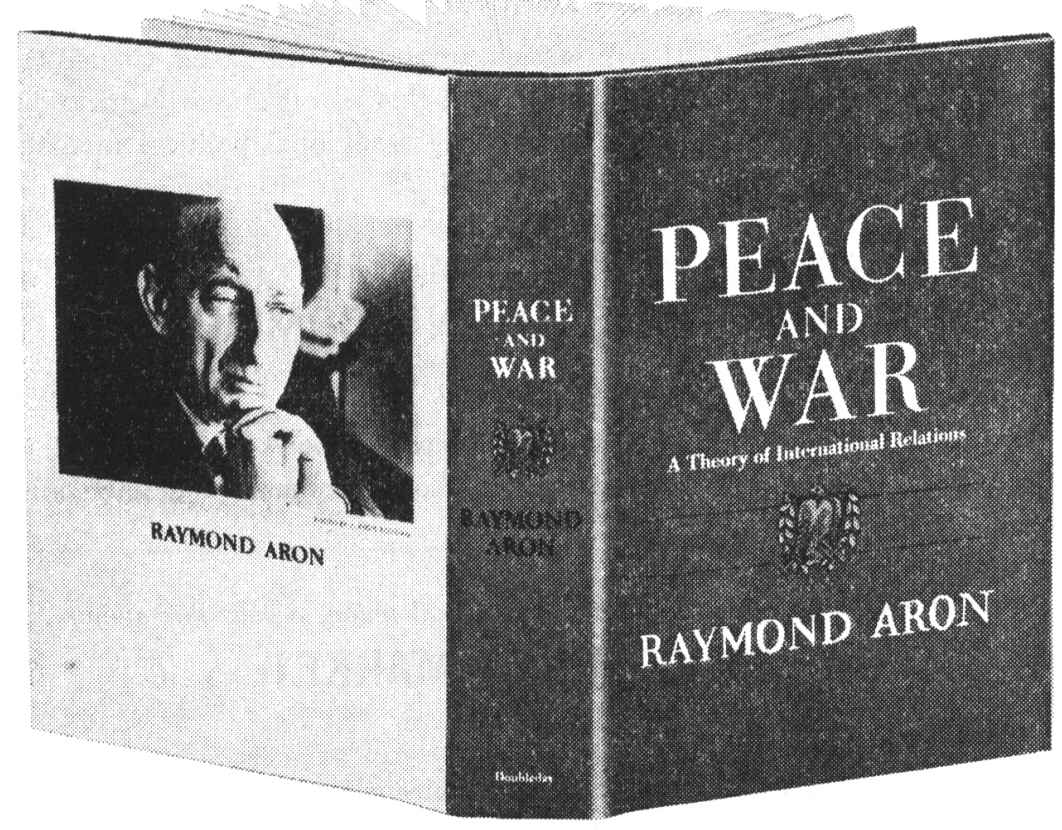

"Far more elaborate and convincing than any of the theoretical forinulations worked out on this side of the Atlantic."-Stanley Hoff. man, Harvard University. ${ }^{1}$

"A recapitulation of everything that politicians and historians have learned over the past thirty or forty years. A more impressive discussion of the nature of war has not been written since Clausewitz."-Golo Mann.2
One of the world's foremost political scientists considers the way in which nations have dealt with one another on the "diplomatic-strategic" level from the beginnings of history to the present, showing the social, cultural and philosophical as well as the political and economic factors that have always entered into such relations and underlining the moral perspectives confronting mankind today. Panoramic in scope, Peace AND WAR expands the reader's horizons and gives new perspective to the day's news. Translated from the French by Richard Howard and Annette Baker Fox, PEACE AND WAR is now at all booksellers. 840 pages, $\$ 10.00$

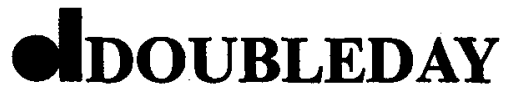




\section{The BIG Issues in Politics from Spectrum / Books...}

POLITICS IN AFRICA-Five political scientists examine the growth of the "master science" in Africa today ...

\section{PATTERNS OF AFRICAN DEVELOPMENT: Five Comparisons}

edited by Herbert J. Spiro, University of Pennsylvania

In this new book, Herbert J. Spiro, Carl J. Friedrich, Ibrahim Abu-Lughod, Claude E. Welch, Jr., and Ali A. Mazrui compare Africa's development with that of other newly-emerging nations of the world, to determine if African nations are repeating traditional political methods or establishing new ones. Feb., 1967 Cloth $\$ 4.95$, paper $\$ 1.95$

THE COMMUNIST WORLD-45 documents illustrate Communism's domestic trials . . .

\section{INTERNATIONAL RELATIONS AMONG COMMUNISTS}

edited by Robert H. McNeal, University of Toronto

Using 45 of the Communist's own pronouncements, the editor shows the ideological, institutional, and historical characteristics of their "closed network" of alignments and antagonisms. March 1967 Cloth $\$ 4.95$, paper $\$ 2.45$

THE COMMON MARKET_An evolving European political union, argues this author . .

\section{THE POLITICS OF THE COMMON MARKET}

\section{by W. Hartley Clark, Carleton College}

The paramount interest of the Common Market is not business and economics, states the author, but politics and the building of a "United States of Europe." Clark examines the policy-making processes of the European league, appraising recent issues and influences. April, 1967 Cloth $\$ 4.95$, paper $\$ 1.95$

ALSO OF INTEREST-A series of volumes on today's nation-states and the historical forces which helped mold them . . .

\section{THE MODERN NATIONS IN HISTORICAL PERSPECTIVE}

Volumes in the series: Argentina - Australia - The Balkans - Central America - Ceylon • China - Cuba, Haiti, and the Dominican Republic - Egypt \& The Sudan - France - India - Indonesia - Italy - Morocco, Algeria, Tunisia • New Zealand • Nigeria \& Ghana - The Philippines - Portuguese Africa - Russia - Scandinavia - Venezuela \& Colombia - West Africa: The Former French States - The West Indies \& The Guianas each volume in the series: cloth $\$ 4.95$, paper $\$ 1.95$

\section{Available at your bookstore}

(Teachers: examination copies available from Prentice-Hall fieldmen. Write for free brochure on Modern Nations series! Spectrum Advertising Dept., Prentice-Hall, Englewood Clifs, N. J. 07632)

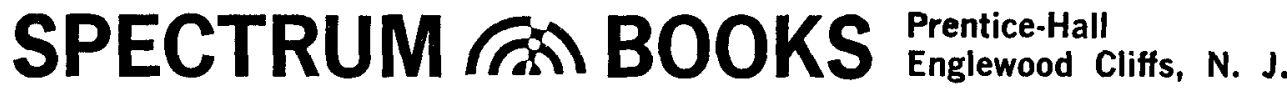

Please mention The American Political Science Review when writing to advertisers 


\section{Do They Know Something You Don't Know? . . .}

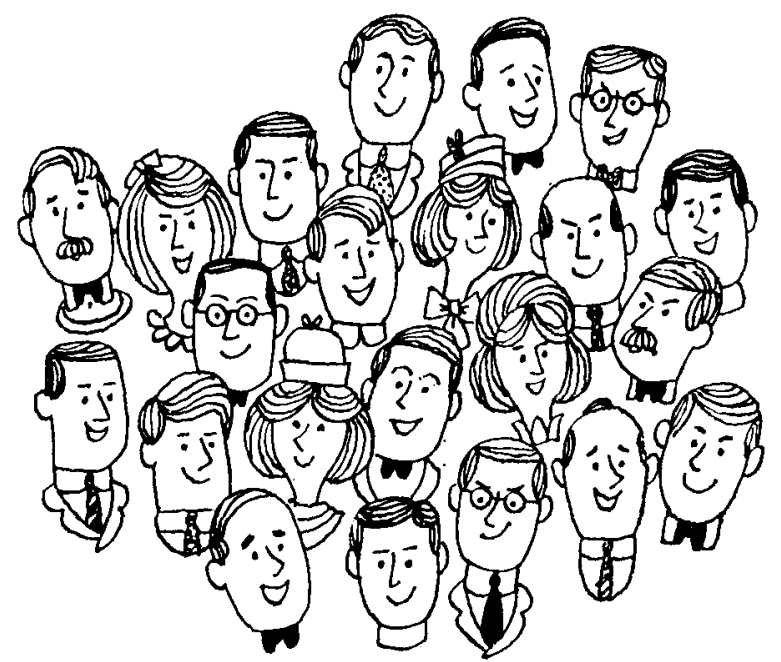

Educators bought 50\% more TIAA life insurance in 1965 than in 1964, the previous all-time high. And the average policy $(\$ 30,000)$ continues to be much higher than the average for companies insuring the general public.

It must be TIAA's new lower premium rates.

For example,

${ }^{\$} 50,000$ Poulc cossis onLy $\$ 98$ at age 30. Here's how:

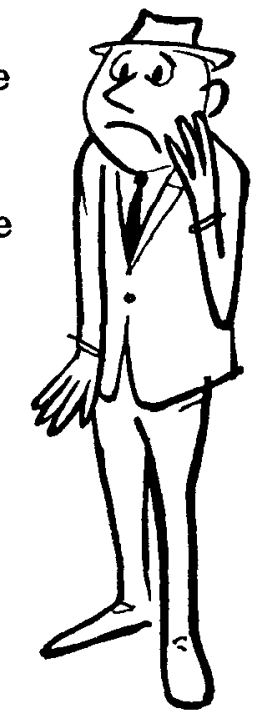

\section{$\$ 50,000$ 20-Year Home Protection Policy}

Age at Issue

Annual Premium (Payable only 16 years)

Cash Dividend End of First Year (based on 1966 dividend scale; not guaranteed for the future)

First Year Net Premium

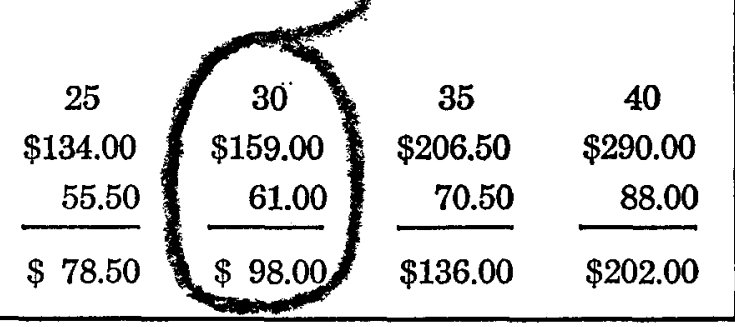

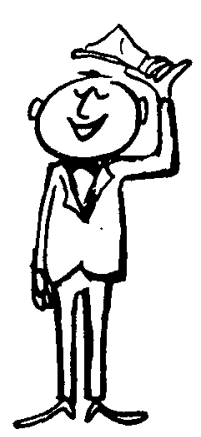

Mail the coupon for the new Life Insurance Guide and a personal illustration of TIAA policies for your age.
This is a plan of level premium Term insurance which provides its largest amount of protection initially, reducing by schedule each year over a 20year period to recognize decreasing insurance needs. There are several other insurance periods, and Home Protection policies are available at all ages under 56.

ARE YOU ELIGIBLE FOR TIAA? Yes, if you are employed by a college, university, private school, or other nonprofit educational or scientific institution that qualifies for TIAA eligibility.

TEACHERS IMSURAHCE AND ANHUITY ASSOCIATIOH

730 Third Avenuo, Hew York, N. Y. 10017

Please mail the new Life Insurance Guide and a personal illustration.

Name

Your

Date of Birth

Address ZIP

Dependents' Ages

Nonprofit Employer

college, university, or other educational or sclentific institution 


\title{
ANNDUNCING
}

\section{POLITICAL CONIINUITY AND CHANGE \\ Peter H. Merkl}

This comprehensive introduction to political theory and comparative government explores the continuity of Western political tradition in terms of some of the seminal concepts of the great political philosophers, examines political institutions and processes of modern government through comparison with the systems of various Western and non-Western countries, and considers processes of revolutionary change as they have affected to the West, and more particularly, today's developing nations. Instructor's Manual. Just published.

\section{and a reminder}

\section{These are the first three volumes in Harper's COMPARATIVE GOVERNMENT SERIES, Michael Curtis, Advisory Editor}

\author{
Latin-American Politics and Government \\ Robert J. Alexander
}

Western European Integration

Michael Curtis

Governments of the Commonwealth

Josephine F. Milburn

\section{Harper \& Row Publishers}
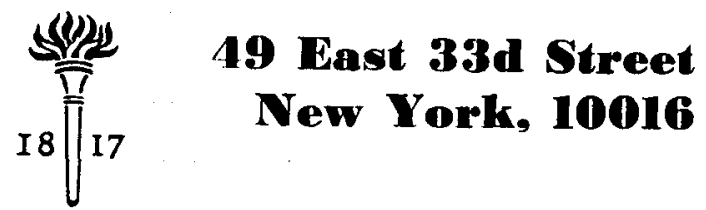

Please mention The American Political Science Review when writing to advertisers 


\title{
Recently Published Volumes in Harper's COMPARATIVE GOVERNMENT SERIRS Is $\int^{17}$ Michael Curtis, Advisory Editor
}

\author{
Eastern European Government and Politics \\ Vaclav Benes, Andrew Gyorgy, and George Stambuk
}

This country-by-country study considers the development and structure of the Eastern European states, their individual Communist parties, the forces that shape their leadership, and their relations with the Soviet Union since World War II. The authors, each a native of the region and an expert in its affairs, strive to effect a balance between two diverging interpretations: that which recognizes very little change in the Eastern European scene and that which exaggerates any appearance of change. 247 pages; $\$ 3.50$ paper

\section{The Government of the German Federal Republic}

\section{Robert G. Neumann}

This analysis of the government and politics of the Federal Republic today includes a brief historical introduction, the controversial issue of German reunification and its political sig. nificance, Germany's place in the European and Atlantic worlds, reasons for her political stability and instability, and points of cooperation and friction between Germany and her neighbors. 192 pages; $\$ 2.75$ paper

\section{Japanese Political Style}

\section{An Introduction to the Government and Politics of Modern Japan}

\section{Warren M. Tsuneishi}

This book introduces the most important aspects of contemporary Japanese politics and government and discusses Japan's geographic and economic foundation, its national characteristics, and historical and constitutional background. 226 pages; $\$ 2.50$ paper

\section{British Government and Politics \\ Douglas V. Verney}

In describing contemporary British political life, the author assumes the basic premise that its significance lies in its adjustment-or inability to adjust-to the loss of an Empire and to the impoverishment caused by two world wars. 226 pages; $\$ 2.50$ paper

\section{Harper a Row, Publishers 49 East 33d Street, New York 10016}




\section{Selection of New Political Science Texts}

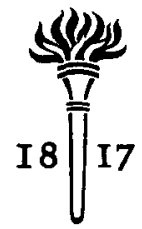

AN INTRODUCTION TO POLITICAL THEORY

Twelve Lectures at Harvard

Carl J. Friedrich

AMERICAN POLITICAL PARTIES

A Systemic Perspective

Charles G. Mayo and Beryl L. Crowe

AMERICAN LAW AND POLITICS

The Creation of Public Order

Roland Young

AMERICAN LEGISLATURES

Structure and Process

George S. Blair

HANDBOOK OF PRACTICAL POLITICS Third Edition

Paul Van Riper, Jr.

CHALLENGE AND DECISION

Political Issues of Our Time, Second Edition

Reo M. Christenson

THE GOVERNMENT AND POLITICS

OF THE UNITED STATES

William C. Havard

AMERICAN GOVERNMENT

Readings and Documents, Second Edition

Peter H. Odegard

Late of University of California, Berkeley

Harper \& Row, Publishers

49 east 33d street, new york 10016 


\section{THE DEMOCRATIC REPUBLIC:}

\section{An Introduction to American National Government}

MARTIN DIAMOND • Claremont Men's College

WINSTON MILLS FISK - Claremont Men's College

HERBERT GARFINKEL • Michigan State University

"This is a major new teaching resource ... a text book with style... The writing is lean and exciting ... The analysis of contemporary institutions and problems is crisp and informative..."

C. Herman Pritchett, University of Chicago

"A great deal of careful planning has gone into this work . . . it includes the historical, the constitutional, the descriptive, and the behavioral approach, but in an integrated fashion so that it can be seen how each contributes to a proper understanding of the American governmental system."

Jerome H. Kerwin, University of Santa Clara

"This perceptive and imaginative book will surely go to the top of the long list of texts for the introductory course in American national government. I am especially pleased by the 'decent respect' it pays to both history and theory ..."

Clinton Rossiter, Cornell University

In 15 chapters, The Democratic Republic provides a comprehensive view of the American political order-a concise, factual account of the essential structure, functions, regulations, and powers of American government. The talents of a political theorist, a constitutional lawyer and a political parties specialist have produced a unified, well-organized book with strong continuity between chapters.

The Instructor's Manual was prepared by Morton Frisch, Professor of Political Science, Northern Illinois University.

\section{Contents}

Part I. Origin of the Republic

1. The Formative Years

2. Framing the More Perfect Union

Part II. Constituting Democracy

3. The Fundamental Political Principles

4. The American Constitutional System: Powers and Constraints

Part III. The Branches of Government

5. The Legislative Branch: Congress

6. The Executive Branch: The Presidency

7. The Judicial Branch: Courts for the American Constitutional System
8. The Administrative System

Part IV. Politics

9. Parties, Politics, and Groups

10. The Political Community: Suffrage, Immigration, and Citizenship

11. Machinery of Representation: Apportionment, Nominations, and Elections

12. Campaigns and Voting Behavior

Part V. Governing

13. Government and Personal Freedom

14. Governing the Economy

15. The Conduct of Foreign Affairs 


\title{
Appleton-Century-Crofts
}

\section{THE SUPREME COURT AND FUNDAMENTAL FREEDOMS, Second Edition}

\author{
GEORGE W. SPICER, University of Virginia
}

A remarkably incisive, brief critical analysis of the Supreme Court as guardian of American civil liberties. The long-awaited revision of this highly regarded study contains additional chapters on civil and criminal procedure and retains the useful sum. mary analysis at the end of each chapter.

February 1967280 pages paperback $\$ 2.45$

\section{A SECOND FEDERALIST: Congress Creates a Government \\ Edited by CHARLES S. HYNEMAN, Indiana University \\ and GEORGE W. CAREY, Georgetown University}

Superbly edited, this compilation of the Congressional debates from 1789 to 1824 , is abridged and excerpted from the Annals of Congress, the most complete record of what was said and done by Congress in its first four decades.

\section{January 1967325 pages paperback $\$ 2.95$}

\section{WORLD TENSIONS: Conflict and Accommodation}

elton atwater, kent forster, and Jan S. Prybyla, all of The Pennsylvania State University

An interdisciplinary approach to world affairs, for students with no previous training in the social sciences. The authors, an historian, political scientist, and economist, examine both the sources and resolution of conflict between sovereign states, conveying a sense of immediacy through illustrations of actual practice of contemporary governments. Features include a series of western and non-western views, in each chapter, on the problems discussed, and guidance on how to prepare a "position paper" on an inter. national issue.

$$
\text { April } 1967400 \text { pages illustrated paperback }
$$

\section{PRESIDENTIAL GREATNESS: The Image and the Man from George Washington to the Present \\ THOMAS A. BaILEY, Stanford University}

Written with wit and incisiveness, this widely reviewed and acclaimed analysis of executive leadership takes a perceptive new look at old stereotypes and establishes criteria for Presidential excellence.

$$
\text { September } 1966386 \text { pages paperback } \$ 3.95
$$

\section{SOURCES IN MODERN EAST ASIAN HISTORY AND POLITICS}

\section{Edited by THEODORE MCNELLY, University of Maryland}

A collection of source materials on the recent history, politics, ideologies, and international relations of China, Japan, Korea, and Vietnam correlated with standard textbooks on the Far East. Introductory notes and headnotes summarize recent Far Eastern history and provide a framework for understanding the significance of the selections. April 1967416 pages illustrated paperback

\section{APPLETON-CEN'TURY-CROFTS \\ Division of Meredith Publishing Company \\ 440 Park Avenue South, New York 10016}

Please mention The American Political Science Review when writing to advertisers 


\section{Appleton-Century-Crofts}

\section{INTERNATIONAL POLITICS, Second Edition \\ VERNON VAN DYKE, The University of Iowa}

Topical rather than historical, this reasoned analysis of the behavior of states in their relations with one another draws not only on diplomatic history, but on psychology, economics, and political theory as well.

April 1966527 pages $\$ 6.50$

OGG AND RAY'S ... .

INTRODUCTION TO AMERICAN GOVERNMENT, Thirteenth Edition

May 1966979 pages illustrated $\$ 8.75$

INTRODUCTION TO AMERICAN NATIONAL GOVERNMENT, Thirteenth Edition

May 1966755 pages illustrated $\$ 7.95$

ESSENTIALS OF AMERICAN GOVERNMENT, Ninth Edition

1965 printing 718 pages illustrated paperback $\$ 4.95$

\section{ESSENTIALS OF AMERICAN NATIONAL GOVERNMENT, Ninth Edition}

1965 printing 550 pages illustrated paperback $\$ 3.95$

all by WILliaM H. Young, The University of Wisconsin

Instructor's manual available for all Ogg and Ray books.

\section{BASIC ISSUES OF AMERICAN DEMOCRACY, Fifth Edition}

Edited by hILlmaN M. BISHOP and SAMUEL HENDEL, both of The City College of New York

Dealing with the fundamental values and persistent issues of our democracy, this bestselling collection of authoritative readings presents a broad spectrum of divergent view. points on the vital questions confronting the American political system.

$$
1965603 \text { pages paperback } \$ 3.65
$$

\section{LEADING CONSTITUTIONAL DECISIONS, Thirteenth Edition}

robert e. Cushman, National Historical Publications Commission, in collaboration with ROBERT F. CUSHMAN, New York University

With decisions as recent as the 1966 Voting Rights case, the thirteenth edition of this highly successful and widely adopted text is the most complete and up to date of the smaller casebooks.

August 1966585 pages paperback $\$ 3.95$

\section{CASES IN CONSTITUTIONAL LAW, 1964-1966}

\section{ROBERT F. CUSHMAN}

The first of a series of inexpensive supplements, designed to bring Cushman and Cushman: Cases in Constitutional Law and all other casebooks fully up to the minute.

December 196673 pages paperback $\$ .95$

\section{APPLETON-CENTURY-CROFTS \\ Division of Meredith Publishing Oompany \\ 440 Park Avenue South, New York 10016}

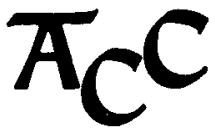




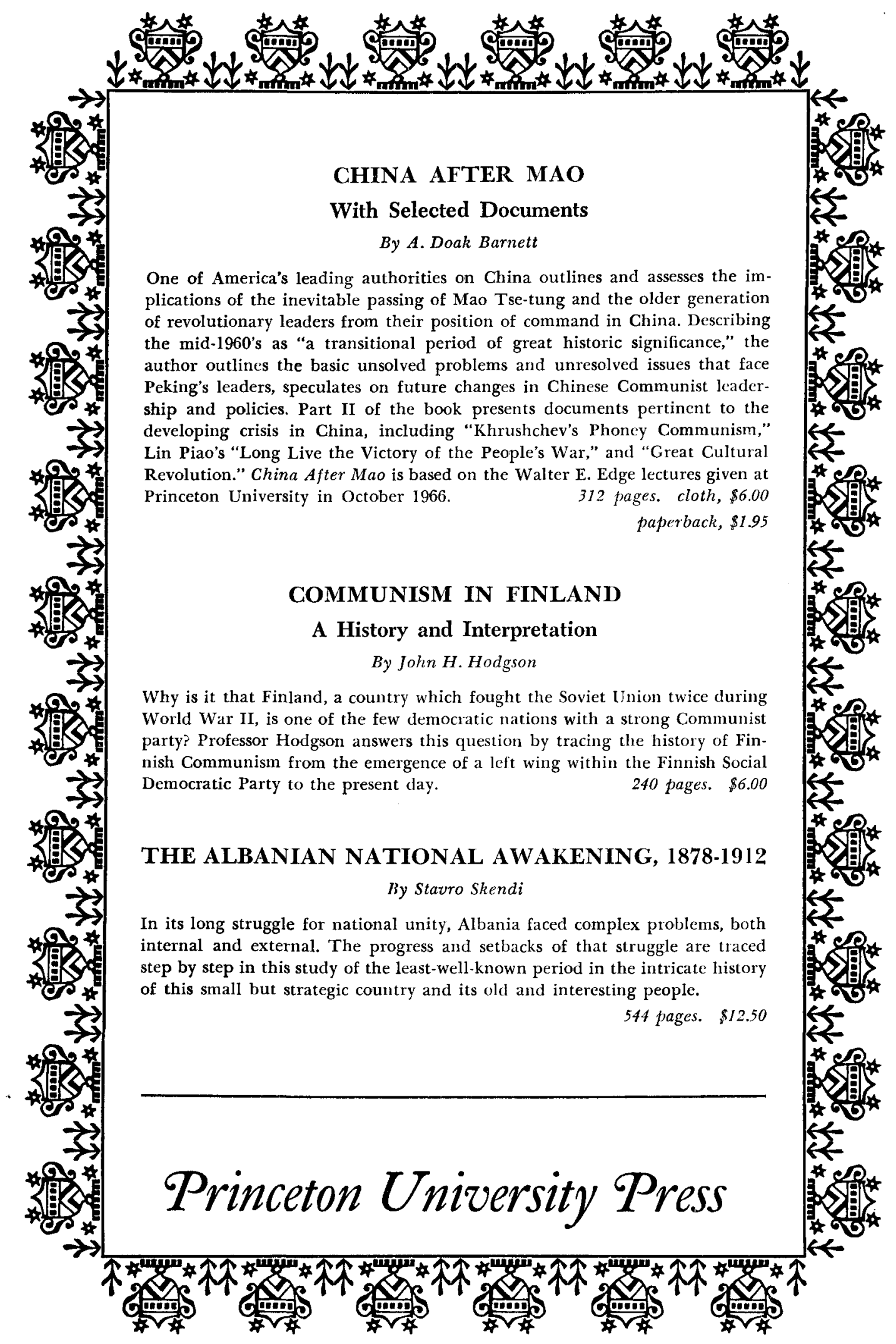

Please mention The American Political Sciexce Rnview when zuriting to adiertisers 


\title{
The Fabric of Democracy: Readings in American Government
}

\author{
329 PAGES $\star 1966$ * PAPER COVER $* \$ 3.50$ \\ Charles P. Blackmore and Abraham Yeselson, \\ Rutgers University
}

Articles and cases illuminating the development, processes, and operation of the American federal system from its beginnings through Lyndon B. Johnson. Men in government and political analysts and critics examine the pressures, stresses, and strengths inherent in the overlapping prerogatives of a federal system. The authors provide an accurate, concise, lucid introduction to each of the thirteen chapters. There are portions of Congressional debates on some currently controversial issues.

\section{CHAPTER HEADINGS AND}

Roots of American Democracy and Constitutional Development

The Declaration of Independence, Thomas Paine, James Madison, Hugo L. Black.

The Nature of Federalism: Conflict and Cooperation Southern Declaration on Integration, McCulloch v. Maryland, General Analysis of Grantsin-Aid, Arthur S. Miller, Lyndon B. Johnson.

The Rights of Free Men

Virginia Statute of Religious Liberty, Abington School District v. Schempp, Gitlow v. New York, Chambers v. Florida, Mapp v. Ohio, Brown v. Board of Education, Senators Stennis and Javitz, Senator Goldwater.

The Political Process

Stephen K. Bailey, Malcolm Moos, Henry Steele Commager, Lyndon B. Johnson, Jack Edwards, How an Election was Bought and Sold (Anon.), Interview with Elmo Roper, John F. Kennedy.

The Legislative Process

Hubert H. Humphrey, The Congress and America's Future, The House Reduces the Powers of Its Committee on Rules, Wesberry v. Sanders.

The Judicial Process

Julius J. Marke, Anthony Lewis, Representative Jamie L. Whitten, Representative Emanuel Celler.

\section{AUTHORS REPRESENTED:}

The Presidency and the National Administration John F. Kennedy, U. S. News \& World Report, Birch Bayh, Jr., Frank C. Porter, Clarence B. Randall.

Financing Government

Leon H. Keyserling, Lyndon B. Johnson, Senator Harry Byrd.

\section{Government and the National Economy}

Ira Wolfert, The Government's Role in Consumer Protection, Neil McElroy.

Government and The Working Man Max Lerner, E. J. Hanley, Emanuel Celler.

Government, The Farmer, and Natural Resources John F. Kennedy, G. D. Arndt, Charles B. Schuman, Thomas W. Glaze, Joseph P. Lyford, Charles A. Reich, Stewart L. Udall, Wayne N. Aspinall.

The National Government and The People's Welfare

Senator Pat McNamara, Senator Tower, Senator Aiken, Lyndon B. Johnson, Edward J. Gurney, Joseph S. Clark.

Foreign Policy and National Defense

Holmes Welch, J. William Fulbright, Lyndon B. Johnson, Walter Millis, Abraham Yeselson.

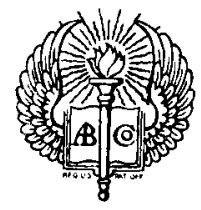




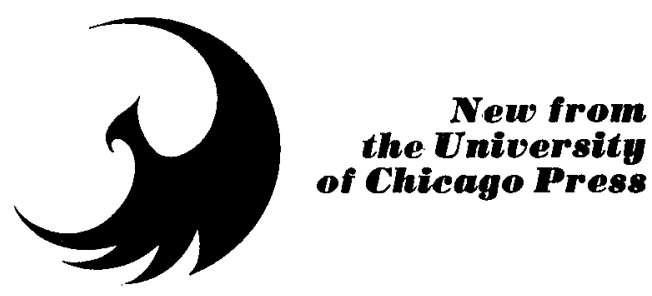

The Court and the Constitution

$A$ series edited by Philip B. Kurland

Melville Weston Fuller

Chief Justice of the United States, 1888-1910

Willard L. King

With an Introduction by Phil C. Neal

The

Unpublished Opinions of Mr. Justice Brandeis

The Supreme Court at Work

Alexander M. Bickel

With an Introduction by Paul A. Freund

John Marshall

James Bradley Thayer

With a Foreword by Mark De Wolfe Howe

The Growth of American Constitutional Law

Benjamin F. Wright

With an Introduction by Robert G. McCloskey
This new paperback series brings back into print in modestly priced editions a number of important books on past Supreme Court Justices and on the role of the Court in American life. As well as filling a need for students of law, political science, government, and history, these volumes will provide, collectively, a history of the Supreme Court.

Melville Weston Fuller presided over the Supreme Court for twenty-two terms-a period in which the Court handed down such important decisions as those on the Income Tax Cases of 1895, the "original-package doctrine," the Insular Cases, and the now discredited "separate but equal" doctrine of Plessy v. Ferguson. In his new Introduction to this biography Phil C. Neal writes, "Fuller emerges in these pages as, among other things, an attractive human being. . . . Our understanding of a major era of the Supreme Court is the richer for this work."

$$
1967416 \text { pages Paper } \$ 2.95
$$

From 1916 to 1939 Louis Dembitz Brandeis opposed the tendency of a majority on the Supreme Court to cling to a "laissezfaire" conservatism. Both without and within the Court, he exerted enormous influence in shaping the social and economic thought of the nation. This book gives the reader a rare opportunity to explore the mind of one of America's greatest jurists. Dean Acheson, in commending Professor Bickel's "excellent book," notes: "For the lawyer who wants a full-length view of Justice Brandeis' judicial methodology it is indispensable."

1967320 pages Paper $\$ 2.45$

First published in 1901, this concise biography remains an eminently readable introduction to the great Chief Justice. Thayer demonstrates that Marshall's most enduring contribution to the nation's welfare lay in his "strong constitutional doctrine, explained in detail, elaborated, powerfully argued, over and over again, with unsurpassable earnestness and force, placed permanently in our judicial records, holding its own during the long emergence of a feebler political theory, and showing itself in all its majesty when war and civil dissension came."

1967196 pages Paper $\$ 1.95$

This brilliant survey evaluates the work of the Supreme Court up to the early 1940 's, when the two great issues of modern constitutional history-the decline of laissez-faire and the rise of civil rights-were just taking shape. In his new introduction Robert G. McCloskey describes Wright as embodying "a deep knowledge of the institutional and intellectual history of America; a political scientist's concern to understand the Court as an operative instrument of government; and a respect for the judicial ideal of rationality and a sharply critical eye for the Court's shortcomings in its pursuit of that ideal."

1967296 pages

Paper $\$ 2.45$ 


\section{The Russian Revolution of 1905}

The Workers' Movement and the Formation of

Bolshevism and Menshevism

Solomon M.Schwarz

Translated by

Gertrude Vakar

Hoover Institution Publications

The Death of Slavery

The United States, 1837-65

Elbert B. Smith

The American Revisionists

The Lessons of Intervention in World War I

Warren I. Cohen

Theory and Practice in American Politics

Edited by

William H. Nelson and Francis L. Loewenheim

Benchmarks

Henry J. Friendly
This book covers the eritical period during 1905 when SocialDemocracy emerged as a factor of consequence on the political scene, only to divide into the two parts that became SocialDemocracy, on the one hand, and, on the other, the authoritarian labor movement that assumed the name of Communism. Solomon M. Schwarz was a Menshevik spokesman on labor affairs and a member of the Kerensky government. His new book, The Russian Revolution of 1905, is the first volume in a comprehensive series, "The History of Menshevism," that will alter the understanding of the Russian revolution. Under Leopold H. Haimson, surviving Menshevik leaders have co-operated to prepare memoirs, monographs, and other scholarly materials. English-language volumes in this series will include "The Making of a Workers' Revolution: Russian Social-Democracy, 1891-1903," by Allan Wildman, and "Menshevism under Soviet Rule," edited by Haimson.

1967 LC:66-20582 384 pages, $\$ 8.95$

This fast-paced account of the crucial pre-Civil War period completes the chronological series of the "Chicago History of American Civilization." Smith's first-hand knowledge of politics gives the work an unusual emphasis which is especially appropriate for the politics of the times.

1967 LC:67-16779 232 pages, $\$ 5.00$

In this original analysis of Revisionism Cohen examines the thinking of those American historians and social scientists who took it upon themselves to persuade their countrymen that they should not have gone to war in 1917. The American Revisionists is an important study of a tradition in American thought which remains alive today among supporters of the Great Society who oppose United States involvement in Southeast Asia.

1967 LC:66-20594 252 pages, $\$ 7.95$

Contributors: Lawrence H. Chamberlain, Carl N. Degler, Felix Gilbert, Dumas Malone, Alpheus Thomas Mason, Ernest R. May, Hans J. Morgenthau, Louis Morton, and Benjamin F. Wright. ". . . a distinguished and timely contribution ... the finest brief analyses of problems in American political thought to appear in the last decade."-Edward N. MacConomy, American Historical Review. 1967165 pages Paper $\$ 1.95$

These articles and lectures by one of America's leading jurists include reflections on the nature of judging, on the federal administrative agencies, and on other problems of deep interest to lawyers and students of government. Four chapters are appreciations of four great judges: Holmes; Brandeis, for whom Judge Friendly was law clerk; Learned Hand, a colleague in the last two years of Judge Hand's long life; and Frankfurter, his teacher and long-time friend.

1967 LC:67-12149 328 pages, $\$ 7.95$

University of Chicago Press, Chicago 60637 
New and recent books

from the Little, Brown College Department

\section{The Power of the Purse}

\section{Appropriations Politics in Congress}

\section{RICHARD F. FENNO, JR., University of Rochester}

The author describes a political process vital to congressional power-the wielding of the power of the purse. He sees the House and Senate as political systems engaged in internal and external activities. The external relationships are those between the committees and House or Senate, between committees and Executive branch, or between two appropriations committees. The internal are those involving methods of organization, committee members' desires and perceptions, etc. This is the most comprehensive treatment ever given to this subject. clothbound 704 pages $\$ 8.75$

\section{The United Nations and U.S. Foreign Policy}

\section{Revised Edition}

\section{LINCOLN P. BLOOMFIELD, Massachusetts Institute of Technology}

Since publication in late 1960 , this book has been accepted as the definitive analysis of the U.N. from the viewpoint of United States' national interest. This major revision reflects the realities in the late 1960's and the problems and prospects for the early 1970's. All sections are thoroughly upated and include new material on international peace keeping, outer space, arms control, and the problem of Communist China. paperbound 288 pages $\$ 2.95$

\section{Foreign Policy and Democratic Politics}

\section{The American and British Experience}

\section{KENNETH N. WALTZ, Brandeis University}

No other book has so systematically compared the British and American political systems in order to discover their foreign-policy capabilities. Professor Waltz critically explores the relationship between internal politics and external policy, and explains policy and process in terms of political structure. He applies an original analysis of political systems to the processes of making and conducting foreign policy, and uses specific cases and problems to illustrate these theories and analyses. paperbound 352 pages $\$ 3.95$ 
to the Little, Brown Series in Comparative Politics

\title{
Comparative Politics
}

\section{A Developmental Approach}

\author{
GABRIEL A. ALMOND and G. BINGHAM POWELL, JR. \\ Stanford University
}

This is a general introduction to the study of comparative political systems. The authors adapt structural-functional and systems theory to politics and treat political systems at three levels. As they review individual functions and classify political systems, the authors develop the themes of structural differentiation and the secularization of political culture. Political development is viewed historically. They examine experiences of individual countries with system development problems of state and nation building, participation, and welfare. Investment strategies in the new and modernizing nations are also considered. paper 348 pages $\$ 2.75$

\section{Politics in Israel}

\section{LEONARD J. FEIN, Massachusetts Institute of Technology}

Based on very recent data, this study offers new insights into the present relationship of two of Israel's major problems: the integration of immigrants, and security. Professor Fein examines the country's dwindling pioneering ideology and explores the nation's quest for a meaningful identity in the 1960's. paperbound 256 pages $\$ 2.75$

\section{Politics in Japan}

\section{FRANK C. LANGDON, University of British Columbia}

Professor Langdon describes the way in which political groups and organizations in Japan combine and interact to effect government policy. He shows how political attitudes are acquired and how political leaders are recruited and trained. This excellent study treats an important "border" country which is significant to the critical relationship of Western to non-Western societies. paperbound 304 pages $\$ 2.95$

\section{Little, Brown College Department} 34 Beacon Street, Boston, Massachusetts 02106 
The expanding Basic Studies in Politics Series

Edited by Sheldon S. Wolin, University of California, Berkeley

Two new additions. .

\title{
The Theory of Democratic Elitism
}

\section{A Critical Analysis}

\author{
PETER BACHRACH, Bryn Mawr College
}

This incisive discyssion of the theory of democratic elitism attempts to reconcile democratic theory and elitist theory. Professor Bachrach views democratic elitism as a basic cause of much recent political theorizing. He attacks democratic elitism as factually unsound empirical theory and as a theory unable to meet normatively the initial political needs of contemporary man. He presents a new theory, founded on the classic principle of self-development, as a meaningful alternative. paperbound 128 pages $53 / 8 \times 81 / 4 \quad \$ 1.95$

\section{Revolutionary Change}

\section{CHALMERS JOHNSON, University of California, Berkeley}

Professor Johnson offers an introductory analysis of revolutionary resorts to violence in society. He utilizes a model of the social system to analyze the causes of revolution and draws upon political theory, anthropology, and social psychology to describe how public actions promote or retard revolutionary conditions. All social science concepts employed in the book are introduced and explained for the student new to social theory. paperbound 208 pages $53 / 8 \times 81 / 4$ $\$ 2.50$

\section{Federalism}

\section{Origin - Operation - Significance}

\author{
WILLIAM H. RIKER, University of Rochester
}

An outstanding volume in the series, this is a concise analysis of the concept of federalism and systems of federalism with the emphasis on the United States. What occasions the adoption of a federal government, what induces societies to keep federal governments they already have? Professor Riker answers these questions by examining past and present federal systems and their workings. paperbound $53 / 8 \times 8 \frac{1}{4} \quad 169$ pages $\$ 1.95$

\section{Political Parties in the American System}

\section{FRANK J. SORAUF, University of Minnesota}

This is an interpretation and analysis of American political parties. Professor Sorauf focuses on the broad outline of the nature and function of the parties, drawing on comparisons with parties of other democracies to add depth to his analysis. He suggests a theory of political parties and, in the last chapter, even suggests in a schematic way the main relationships between party functions and organization on the one hand and the general political and social system on the other. paperbound $53 / 8 \times 81 / 4 \quad 194$ pages $\$ 1.95$ 


\title{
American Political Patterns
}

\section{Conflict and Consensus}

\author{
DAN D. NIMMO, University of Houston \\ THOMAS D. UNGS, Wichita State University
}

Nimmo and Ungs describe the principal patterns of American political behavior within the consistent theoretical framework of conflict representation.

In American communities social conflict is regulated by certain patterns of behavior. Examination of these patterns reveals an underlying consensus necessary to the preservation of the community.

Representation in American government is a process of communication that brings the conflict to light through patterns of participation, opinion, leadership, choice, partisanship, and pressure.

Resolution is a process of accommodation that keeps conflict within manageable limits through policy-making. Officials make binding public policy with acts of formulation, leadership, adoption, application, and adjudication.

The style of American Political Patterns is particularly clear. Nimmo and Ungs include only truly relevant examples to illustrate basic principles of American democratic government.

clothbound

$6 \times 9$

480 pages

$\$ 5.95$

Little, Brown College Department

34 Beacon Street, Boston, Massachusetts 02106 


\section{Exceptional publications treating}

the basic issues in American Government:

\section{GOVERNING THE AMERICAN NATION}

By Richard H. Leach, Duke University. Just Published, 1967. "It is a solid, professional piece of work ... of high quality, excellent teachability." Peter Woll, Brandeis University, from a pre-publication review. College list $\$ 8.95$.

\section{INSTITUTIONS AND PRACTICES OF AMERICAN GOVERNMENT}

By William C. Havard and David R. Mayhew, both of the University of Massachusetts. Scheduled April 1967 publication. "I find this a highly promising collection of readings. It has several advantages over many of the other reading books in the field. More notably, the editors have avoided the kind of proliferation which marks so many efforts and which bewilders students through such a variety of riches." Gordon Baker, University of California, Santa Barbara, from a pre-publication review. College list $\$ 5.50$ tent.

\section{AMERICAN GOVERNMENT Behavior and Controversy}

By Lewis Lipsitz, University of North Carolina, Chapel Hill. Scheduled March, 1967 publication. "I have reviewed [the text]. It has excellent materials, a widely read and intellectually sensitive editor, and a definite role within the college community. . .." Edgar Litt, University of Wisconsin, Milwaukee, from a pre-publication review. Paperbound. College list $\$ 5.25$ tent.

\section{ALLYN AND BACON, INC.}

\section{POLITICAL PARTIES AND POLITICAL BEHAVIOR}

By William J. Crotty, Northwestern University; Donald M. Freeman, University of Arizona; and Douglas S. Gatlin, Florida Atlantic University. Just Published, 1966. "It is a superior work, one which I would very probably use in a course on parties and one which I would seriously consider for an introductory course in American Government. . . ." Joseph Cooper, Harvard University. College list $\$ 6.25$.

\section{THE JUDICIARY: The Supreme Court in the Governmental Process}

By Henry J. Abraham, University of Pennsylvania. Recently Published, 1965. Part of the Allyn and Bacon Series in American Government, Consulting Editor: William Beaney. Paperbound. College list $\$ 1.95$.

\section{STATE AND LOCAL GOVERNMENT IN AMERICA}

By Daniel R. Grant, Vanderbilt University; and H. C. Nixon, Professor Emeritus, Vanderbilt University. College list $\$ 8.50$. 


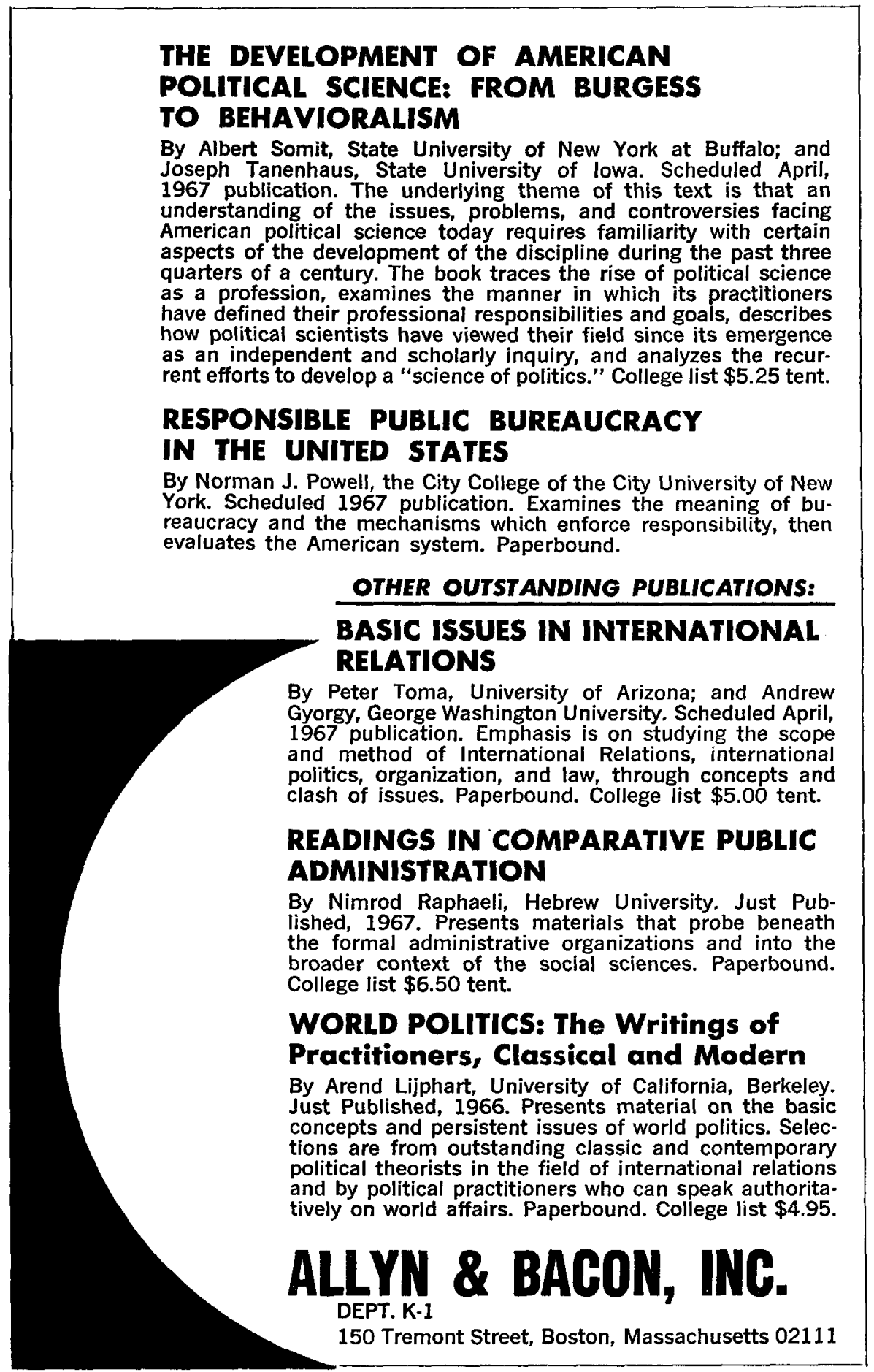

Please mention Tur American Political Science Review when writing to advertisers 


\section{Important New Texts From}

\section{THE RELATIONS OF NATIONS,}

\section{Third Edition}

\section{By Frederick H. Hartmann, Naval War College}

Thoroughly revised and updated, the Third Edition of this text continues to provide a systematic analysis of international politics in a careful combination of theory and historical data. The book progresses from general background material to specific relations between countries, and case studies are used throughout. Numerous charts, tables, and maps illustrate the text.

1967, approx. 752 pages, prob. $\$ 8.95$

\section{WORLD IN CRISIS Readings in International Relations Third Edition}

\section{Edited by Frederick H. Hartmann}

Here is a collection of essays which provides the student with the stimulating thinking of scholars and statesmen on all major aspects of international relations. More than one half of the selections in this edition are new. Each of the selections is given at sufficient length to develop fully the contributor's position and contrasting views are frequently represented. New to the book is a complete case study of the Cuban Crisis and a chapter on Vietnam.

1967, approx. 448 pages, prob. $\$ 3.95$

Write to the faculty service desk for examination copies.

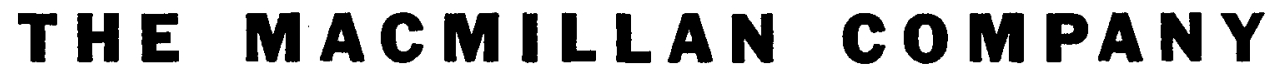




\section{Macmillan In Political Science}

\section{THE CONSENT OF THE GOVERNED, second Edition}

By John C. Livingston and Robert G. Thompson, both of Sacramento State College

The Second Edition of this successful text has been sharpened and clarified by estab. lishing, in the first four chapters, the democratic frame of reference needed before proceeding to an examination of American practices and institutions. The authors then pose questions about the nature of democracy and present their answers as well as those propounded by liberal, conservative, and "brokerage" theory. There is a detailed outline at the beginning of each chapter and a list of suggested readings are provided at the end of the book.

1966, 608 pages, $\$ 6.95$

To Accompany the Text . . Examine these selections from the GOVERNMENT IN THE MODERN WORLD SERIES

\section{The Democratic Party in American Politics}

By Ralph M. Goldman, San Francisco State College

1966,160 pages, paper, $\$ 1.50$

Presidential Leadership: Personality and Political Style

By Erwin C. Hargrove, Brown University

1966, 153 pages, paper, $\$ 1.50$

Interest Groups and Lobbying

By Abraham Holtzman, North Carolina State University

1966, 154 pages, paper, $\$ 1.50$

The Republican Party in American Politics

By Charles O. Jones, University of Arizona

1965,160 pages, paper, $\$ 1.50$

The Supreme Court in the Political Process

By Samuel Krislov, University of Minnesota

1965, 155 pages, paper, $\$ 1.50$

The Role of Government in the American Economy

By Emmette S. Redford, The University of Texas

1966, 160 pages, paper, $\$ 1.50$

866 Third Avenue / New York, N.Y. 10022

Please mention The Axmoican Political Science Review when writing to advertisers 


\section{IDEOLOGIES IN WORLD AFFAIRS}

\section{Andrew Gyorgy, George Washington University}

George Blackwood, Boston University

Ideologies or "ism's" may be defined as concise sets of economic, political, and social beliefs governing the lives of societies. In an increasingly political world, ideologies play a crucial role. This introductory text examines such questions as the role of ideas in world affairs; the nature and characteristics of an "ideology"; and the distinction between political parties and political movements. In answering the key question, What is an ideology?, the authors classify today's major "ism's" into such free world ideologies as capitalism, democracy, and socialism, and into such ideologies of dictatorship as the various forms of fascism, national socialism, and communism.

1967. 272 pages. Paperbound. $\$ 3.50$

\section{CONSTITUTIONALISM IN AMERICA}

Origin and Evolution of its Fundamental Ideas

\section{Arthur E. Sutherland, Harvard University Law School}

This book is a history of five constitutional ideas: rule by majority will, justice despite majorities, equality of man, diffusion of governmental power, and the ideal of a fundamental written law. The author traces their origin and growth from Magna Carta through five centuries in England; through a century and a half in Colonial America; and through the experience of the United States from independence to present day.

1965.618 pages. $\$ 9.50$

\section{CONSTITUTIONAL GOVERNMENT AND DEMOCRACY, Revised Edition}

\section{Carl J. Friedrich, Harvard University}

This well-known text studies the nature and development of modern government, the pattern of constitutional government, the functioning processes of constitutional government, and governmental tension, breakdowns, and adjustments.

1950. 688 pages. $\$ 9.50$

\section{MATHEMATICAL MODELS IN THE SOCIAL SCIENCES}

\section{John J. Kemeny, Dartmouth College}

\section{J. Laurie Snell, Dartmouth College}

This text is appropriate for use in a one-semester course at the junior level which requires as prerequisites a year of calculus and a course in finite mathematics. As such it is important in the mathematics curriculum, but it can be used and understood by social scientists. After the general introduction the authors present a series of cases which can be chosen by the instructor and presented in an order which is flexible.

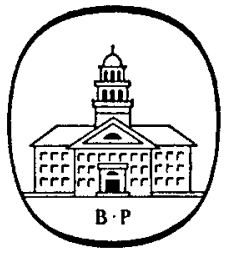

1962. 145 pages. $\$ 8.50$

\section{BLAISDELL PUBLISHING COMPANY}

\section{A Division of Ginn and Company}

275 Wyman Street, Waltham, Massachusetts 02154 


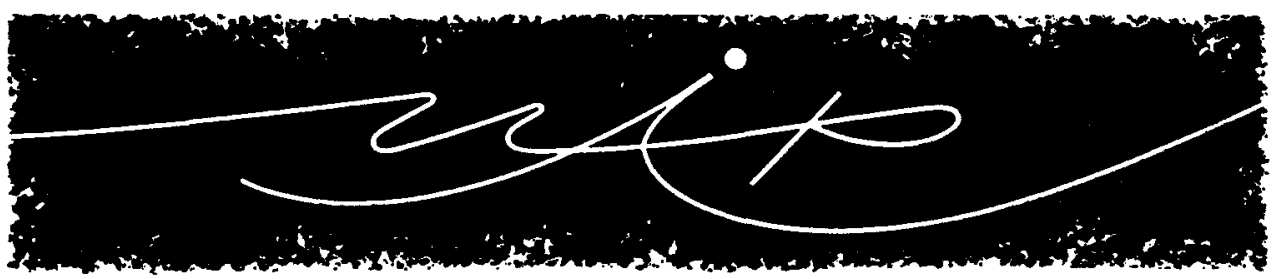

\section{FEDERALISM AND SUPRANATIONAL ORGANIZATIONS}

\section{Patterns for New Legal Structures}

by Peter Hay

Increasing economic interdependence and the need for transnational cooperation have given rise to new types of international organizations, particularly since World War II. Using the three European Communities as models, these timely essays explore the nature of supranational organizations, the techniques they utilize, and their contribution to the formulation of international law. The author offers a provocative discussion of the constitutional problems that would evolve from United States participation in such Communities and examines similar adjustments being effected in Germany under the Bonn Constitution. 335 pp. $\$ 7.50$.

\section{INTERNATIONAL TRADE, INVESTMENT, AND ORGANIZATION \\ edited by Wayne R. LaFave and Peter Hay}

In this comprehensive introduction to the rapidly expanding area of international trade and investment, nineteen authorities in the field examine current practical problems of international trade, its regulation by regional international organizations, and the impact of these organizations on the development of uniform standards and legal norms. The wide range of topics discussed include basic trends in East-West trade, the move to reduce tariff restrictions, incorporation of American business abroad, regional trade associations, and the implications of economic association among underdeveloped countries. 499 pp. $\$ 7.50$.

\section{THE POLITICS OF WAGE-PRICE DECISIONS}

\section{A Four-Country Analysis}

\section{by Murray Edelman and R. W. Fleming}

Here is a multifaceted evaluation of the ways in which Italy, Germany, Great Britain, and The Netherlands have attempted to exert a restraining influence on price and wage levels since World War II. It includes a comparison with the United States that throws light upon current American wage-price decisions and policies. ". . . a firstrate piece of work, subtle and well informed."-The Journal of Politics. 331 pp. $\$ 6.75$.

\section{WHITE-COLLAR TRADE UNIONS \\ Contemporary Developments in Industrialized Societies edited by Adolf Sturmtbal}

The past, present, and future of white-collar trade unionism and its implications for traditional blue-collar unions in Australia, Austria, France, Germany, Great Britain, Japan, Sweden, and the United States are traced and analyzed by authorities in each of these countries in this timely and important book. 412 pp. $\$ 7.95$.

\section{THE UNIVERSITY OF ILLINOIS PRESS, URBANA, ILLINOIS}

Please mention The American Political Sctence Review when writing to advertisers 


\section{Introduction to Political Science}

Recently published...

\section{GOVEIRMMENT AND POLITICS}

An Introduction to Political Science

Edited by JOHN C. WAHLKE, University of Iowa and

ALEX N. DRAGNICH, Vanderbilt University

Random House, $1966 ; 624$ pages; $\$ 7.95$

A collaborative effort by eight specialists, this new text combines description of political systems with analysis of the nature of political science itself. The resulting perspective affords a broad, systematic, and unified introduction to the whole field of political science.

In preparation ... the Third Edition of

\section{COMMUNISM}

by ALFRED G. MEYER, The University of Michigan

PS34; about 220 pages; about $\$ 1.95$ paperbound

A brilliant, short introduction to the study of communism as a system of ideas, a political movement, and a form of government.

\section{INTRODUCTION TO GOVERNMENT}

Third Edition, Revised

by ROBERT REINOW, State University of New York, Albany

Knopf, 568 pages; $\$ 7.95$

A study of the principles of government based on comparative methods, with particular emphasis on government in the United States, this introductory text offers a detailed examination of the forces at work in political decision-making. The present edition, carefully revised and brought up to date, is written in the same straightforward and engaging style that won immediate favor for the earlier editions, and takes full account of the most recent findings of behavioral research on voting, elections, legislatures, and legislative behavior.

\section{Legislative Process \\ THE LEGISLATIVE PHOCESS IN THE UNITED STATES}

by MALCOLM E. JEWELL, University of Kentucky and

SAMUEL C. PATTERSON, University of Iowa

Random House, $1966 ; 589$ pages; $\$ 7.95$

A wide-ranging survey of the legislative process in this country as it can be studied in Congress and the fifty state legislatures. The authors discuss in detail the multitudinous aspects of American legislatures: the role of executives in the legislative process; legislators and their backgrounds; and legislative voting behavior.

\section{CONGRESS MAKES A LAW}

by STEPHEN KEMP BAILEY

V511; 304 pages; $\$ 2.45$ paperbound

\section{Congress Politics and Practice}

by NORMAN C. THOMAS

The University of Michigan

and KARL A. LAMB

University of California, Santa Cruz

PS45; 155 pages; $\$ 1.95$ paperbound

For further information, write to

RANDOM HOUSE \& ALFRED A. KNOPF, Inc. 


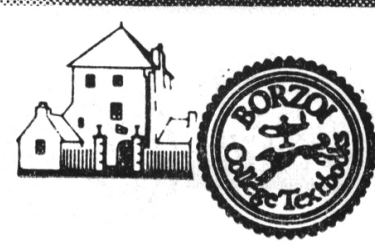

Just published ...

THE FIFTY STATES and Their Local Governments

JAMES W. FESLER, Editor, Yale University, KARL A. BOSWORTH, University of Connecticut, DAYTON D. McKEAN, University of Colorado, HARVEY C. MANSFIELD, Columbia University, ROBERT L. MORLAN, University of Redlands, ALLAN R. RICHARDS, Louisiana State University, VICTOR G. ROSENBLUM, Northwestern University, YORK WILLBERN, Indiana University.

Knopf, February $1967 ; 640$ pages; $\$ 8.50$

A revision and substantial expansion of THE 48 STATES, on which six of the present authors collaborated. Its focal concern is the capacity of state and local governments to exercise power responsibility, democratically, intelligently, and efficiently.

\section{THE STATE LEGISLATURE}

\section{Politics and Practice}

by MALCOLM E. JEWELL, University of Kentucky

A short, but comprehensive study of the realities of party politics and legislative behavior at the state level.

PS37; 152 pages $\$ 1.45$ paperbound

\section{THE STUDY OF LOCAL POLITICS}

by WILLIAM H. RIKER, Lawrence University

An introduction to the subject of field research in politics, prepared especially for the undergraduate student.

PS29; 126 pages; $\$ .95$ paperbound

\section{THE REAPPORTIONMENT REVOLUTION}

Representation, Political Power, and The Supreme Court

by GORDON E. BAKER, University of California, Santa Barbara PS20; 192 pages $\$ 1.95$; paperbound

A survey of the background and issues involved in one of the most important problems facing American government today. An appendix gives excerpts from the most significant recent Supreme Court cases on reapportionment.

\section{RULE 9: POLITICS, ADMINISTRATION, AND CIVIL RIGHTS}

by NORMAN C. THOMAS, The University of Michigan

PS57; 144 pages; $\$ 1.95$ paperbound

A case study of policy making by an administrative rather than a legislative branch of state government.

\section{THE POLITICAL THEORY OF AMERICAN LOCAL GOVERNMENT}

by ANWAR SYED, University of Massachusetts PS54; 224 pages; $\$ 2.25$ paperbound A synthesis of what American political philosophers, from Jefferson to the present, have thought about local government and its place in the American system.

\section{Civil Rights}

Available in a Second Edition

COURTS AND RIGHTS The American Judiciary in Action by JOHN ROCHE, Brandeis University PS36; 160 pages; \$1.95 paperbound Examines the role of America's judicial institutions in the struggle for civil rights.

\section{THE POLITICS OF CIVIL RIGHTS}

by CHARLES V. HAMILTON, Lincoln University

This incisive study of Negro civil rights in America stresses the inadequacy of "traditional" political processes and the need for innovation in dealing with civil rights issues. Fall 1967; PS56; 192 pages; $\$ 1.95$ paperbound 


\section{Comparative Government}

\section{PATTERAS DF GOVERNMENT}

The Major Political Systems of Europe

Second Edition, Revised and Enlarged

by SAMUEL H. BEER and ADAM B. ULAM, Harvard University,

HARRY ECKSTEIN and NICHOLAS WAHL, Princeton University, and

HERBERT J. SPIRO, University of Pennsylvania

Random House, 832 pages; 18 tables and figures; $\$ 7.95$

Substantially expanded and updated, this is the revised edition of a book which has estab-

lished itself as one of the foremost texts in comparative government on the introductory level.

Recently published...

\section{DOCUMENTS DF MAJDH EUROPEAN GOVERNMENTS}

by RANDOLPH L. BRAHAM, The City College of The City University of New York

Knopf, 1966; 224 pages; $\$ 2.45$ paperbound

Brings together (either complete or in carefully-edited excerpts) the constitutions, electoral laws, most recent party programs, and post-World War II election results of Great Britain, France, Germany, and the USSR. Compact, yet comprehensive, the collection can be used with any standard comparative government text.

Winner of the Woodrow Wilson Foundation Award for 1965

\section{IBITISH POLITICS IN THE}

\section{COLLECTIVIST ARE}

\section{by SAMUEL H. BEER, Harvard University}

Knopf, $1965 ; 384$ pages; $\$ 5.95$

An assessment-in-depth of contemporary British political life, this new book focuses on the role of parties and interest groups in the formation of public policy. Professor Beer discusses present-day British politics-Labour and Conservative-in terms of the historical evolution of political behavior in Britain since the sixteenth century.

In preparation...

\section{USSR 50 YEARS LATER}

The Promise and the Reality

Edited by SAMUEL HENDEL and RANDOLPH L. BRAHAM,

The City College of The City University of New York

Knopf, Summer 1967; about 400 pages; about $\$ 3.95$ paperbound

Nine specialists assess the record of the Soviet Union: the political system in general, the economy, social and cultural developments, relations with other Communist states, the USSR in world affairs, and the future of the Soviet Union.

Revised Edition

Recently published...

\section{THE FOREIGN POLICY DF THE SOVIET UNION Revised Edition}

Edited by ALVIN Z. RUBINSTEIN, University of Pennsylvania

Random House, $1966 ; 458$ pages; $\$ 4.95$ paperbound

A new edition in paperback of a comprehensive collection of readings on Soviet foreign policy since 1917. The present revision includes selections on the USSR-Cuba dispute, the nuclear test-ban treaty, and the changing Soviet attitude toward India.

Newly revised

THE GOVERNMENT AND POLITICS OF THE SOVIET UNION

by LEONARD SCHAPIRO V176; 194 pages; $\$ 1.95$ paperbound

For further information, write to

RANDOM HOUSE \& ALFRED A. KNOPF, Inc. 
Just published ... the Fourth Edition of

\section{POLITICS AMONG NATIONS}

The Struggle for Power and Peace

by HANS J. MORGENTHAU, University of Chicago

Knopf, January 1967; 672 pages; $\$ 7.95$

Professor Morgenthau appraises the fateful struggle of sovereign states for power and peace in our time in what is still the most comprehensive and useful survey in the field of contemporary international politics.

\section{THE MIGHT OF NATIONS}

Revised Edition

World Politics in Our Time

by JOHN G. STOESSINGER, Hunter College of The City University of New York

Foreword by Arthur N. Holcombe

Random House, 1965 ; 460 pages; $\$ 6.75$

The revised and updated edition of the text won the Bancroft Prize in International Relations. The major problems of international politics, organization, and law are covered, including such recent developments as the liquidation of the African colonies, disarmament negotiations, and the U.N. financial crisis.

\section{CRISIS AND CONTINUITY IN WORLD POLITICS}

Readings in International Relations

Edited by GEORGE A. LANYI and WILSON C. McWILLIAMS, both of Oberlin College Random House, 1966; 768 pages; $\$ 4.95$ paperbound

An important new anthology of extraordinary range and scope, offering significant readings on the abiding issues of international relations by writers from Machiavelli to the leading contemporary scholars and commentators.

\section{Theory and Methods of Political Science}

In preparation...

\section{CONTEMIPOHARY RADICAL IDEDLOGHES}

by A. JAMES GREGOR, University of Texas

Random House, Fall 1967; about 450 pages; about $\$ 4.95$

A description and original analysis of the major radical ideologies of our time: Leninism, Fascism, National Socialism, Apartheid and African Socialism. Drawing extensively on primary source material, the accounts of each system are compact but thorough and balanced in coverage. Especially notable are the chapters on Fascism and Apartheid, since there are few comprehensive accounts in English of these systems as ideologies.

Recently published...

\section{POLITICAL BEHAVIOR IN AMERICA}

New Directions

Edited by HEINZ EULAU, Stanford University

Random House, 1966; 455 pages; $\$ 6.95$ hardcover, $\$ 4.95$ paperbound

A major collection of significant readings on political behavior in the United States, illustrating important trends in research and in the development of theory and methodology. This is a companion volume to Professor Eulau's THE BEHAVIORAL PERSUASION IN POLITICS (A Random House Study in Political Science). 


\section{THE AMERICAN POLITICAL SYSTEM:}

\section{Notes and Readings}

Edited by BERNARD E. BROWN, Brooklyn College of the City University of New York, and JOHN C. WAHLKE, The University of lowa

Systematic, analytic, and dynamic, this new text encourages students to view the United States as one political system among many. To this end, the editors have organized the material around the theme "systems analysis." After exploring some problems of methodology, the student has his attention directed to the following topics: (1) legitimacy and consensus, (2) political dynamics, (3) decision-making and policy formulation, and (4) political change. Each of these topics is spelled out as an analytic category in terms of which the American or any other political system may be examined. In viewing and analyzing the American political system in terms of these four categories, the student will be able more easily to compare the United States with other nations, to identify the similarities and differences, and to recognize the unique and the universal. This book is valuable as a supplementary text for introductory courses in American government or political science.

682 pages

Paperbound

Text price: $\$ 4.75$

\section{CONGRESS AND FOREIGN POLICY-MAKING:}

\section{A Study in Legislative Influence and Initiative, Revised Edition}

By JAMES A. ROBINSON, The Ohio State University

With more than one third of its material completely rewritten, this text continues to give students excellent and up-to-date insight into the influence of Congress on U. S. foreign policy. New material has been incorporated on legislative-executive relations regarding foreign policy, and on the frequency of communications with members of Congress. This Revised Edition also includes a newer and more extensive analysis of how variations in communications processes among Congressmen affect their voting on foreign policy legislation. The book concludes with a reappraisal of Congress' role in foreign policy.

About 300 pages Paperbound Tentative text price: $\$ 3.50$

\section{Write Today to Reserve Your Examination Copies}

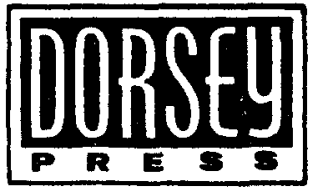

Published in The Dorsey Series in Political Science

\section{THE DORSEY PRESS}

Please mention The American Politicat Scrence Review when writing to advertisers 


\section{The Dorsey Series in Political Science}

THE LANGUAGE OF MODERN POLITICS

An Introduction to the Study of Government

By H. MARK ROELOFS, New York University

This book presents to the beginning student an important point of view: that politics should be studied for what it is-a distinctly human activity in which men attempt to converse about and communicate their problems. The student is also given a conceptual framework with which to discover and interpret information for himself. Roelofs' text is purposely brief, each chapter written with an eye toward the special appendix listing paperbacks which might be assigned as collateral reading. About 550 pages; Tentative text price: $\$ 8.25$

\section{CONTEMPORARY POLITICAL THEORY}

By EUGENE J. MEEHAN, Brandeis University

A critical, analytic study, this book analyzes discussions now taking place in the field about methodological, conceptual, and evaluative problems in the study of politics. It provides a framework useful for examining major works produced recently, and a framework in which the study of political thought can be made relevant to the study of politics generally. About 600 pages; Tentative text price: $\$ 8.50$

\section{THE ELEMENTS OF INTERNATIONAL LAW, Revised Edition}

By GERARD J. MANGONE, Syracuse University

Greatly expanded and completely updated, this new Revised Edition presents additional introductory text material for each section of cases and documents. Current materials have been added to almost every subject, especially in problems of jurisdiction and the legal regulation of international force. The opinions from national and international courts have been combined with cogent essays by the author. About 550 pages; Tentative text price: $\$ 8.25$

\section{PATTERIS OF SOVIET POLITICS, Revised Edition}

\section{By RICHARD C. GRIPP, San Diego State College}

Expanded and reorganized, this new edition provides recent information on such developments as Khrushchev's downfall, the new five-year plan, the 23rd Congress of the CPSU, and related governmental and political changes since 1936. Discussed are such concepts as political socialization and recruitment and legitimacy regarding the Soviet political system. An expanded final chapter elaborates summary concepts on the patterns of Soviet politics. About 400 pages; Tentative text price: $\$ 7.75$

\section{THE NATURE OF POLITICAL INQUIRY}

BY FRED M. FROHOCK, Syracuse University

Bringing together both classical and modern political theory at a methodological level, this book defines political inquiry through a discussion of the necessary role of theory in investigation. The wide range of problems scrutinized makes this text an appropriate volume for both undergraduate and graduate courses and seminars. About 250 pages; Tentative fext price: $\$ 5.00$

Consulting Editor: Norton E. Long, Brandeis University

\section{HOMEWOOD, ILLINOIS}

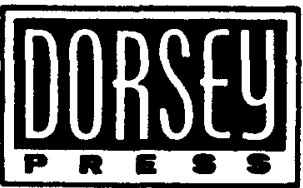

Pleose mention The Americax Political Science Review when writing to advertisers 


\section{$-F_{P}$}

\section{Domestic Sources Of Foreign Policy}

\section{Edited by James N. Rosenau, Rutgers University}

The first multidisciplinary approach to the study of the influence of domestic factors in the formulation and conduct of foreign policy. Excerpts from several disciplines-political science, sociology, and psychology-discuss such topics as voting and foreign policy, mass communications and foreign policy, and the significance of various interest groups. Among the contributors are Bernard $\mathrm{C}$. Cohen, Scott Greer, Theodore J. Lowi, Herbert McClosky, Lester W. Milbrath, and Warren E. Miller.

Just Published

352 pages (approx.)

$\$ 7.50$ tent.

\section{International Politics And Foreign Policy}

A Reader in Research and Theory

\section{Edited by James N. Rosenau, Rutgers University}

Fifty-five selections from the work of Gabriel Almond, Karl W. Deutsch, Morton Kaplan, Arnold Wolfers and others present a remarkably broad range of contemporary theory and theoretical approach. "... brings together a comprehensive selection of articles covering most aspects of the advancing field.... I find Rosenau's selection very satisfying, in the sense that I cannot think of anything else I want to put in ... here is an excellent broad sample of recent writing." -Kenneth E. Boulding, The Journal of Confict Resolution 1961

511 pages

$\$ 8.95$

\section{Contemporary Political Analysis}

\section{Edited by James C. Charlesworth, University of Pennsylvania}

Twenty distinguished contributors including Heinz Eulau, James N. Rosenau, Karl W. Deutsch, David Easton, and Andrew Hacker discuss and evaluate the major contemporary methodologies in political science research. Each of eight research approaches-behavioralism; functional analysis; the quantitative approach; systems theory; decision-making theory; game theory; communications theory; and political development theory-is described, analyzed, and evaluated. July, 1967 480 pages (approx.)

$\$ 7.95$ tent. 


\title{
Quantitative International Politics
}

\author{
Insights and Evidence
}

\section{Edited by J. David Singer, University of Michigan}

Volume Six in the Series International Yearbook of Political Behavior

Research, Heinz Eulau, General Editor

The work of fourteen political scientists and historians has been gathered in the first book-length presentation of data-based studies to touch all areas of international politics. The contributors demonstrate how the rigorous methodology of the behavioral disciplines can be brought to bear on the raw information of world politics to sort out useful data, test hypotheses, and support meaningful generalizations.

May, 1967

352 pages (approx.)

$\$ 8.50$ tent.

\section{Knowledge And Power}

\section{Essays on Science and Government}

\section{Edited by Sanford A. Lakoff, State University of New York at Stony Brook}

Fifteen authoritative readings, none of which has ever before appeared in book form, consider the controversies and modern relationships between science and government. Included are an examination of the President's Science Advisory Committee, the Oppenheimer case, Project Mohole, NASA, the nuclear test-ban controversy, and the Congressional inquiry into smoking and health. Daniel S. Greenberg, McGeorge Bundy, Stanley J. Reiser, Carl W. Fischer, Harvey Brooks, and Alan T. Waterman are among the distinguished contributors.

$1966 \quad 550$ pages

$\$ 9.95$

\section{Congressmen And The Electorate} Elections for the U.S. House and the President, 1920-1964

\section{By Milton C. Cummings, Jr., Johns Hopkins University}

The first thorough analysis of the way Americans have voted for the President and for congressmen from 1920 to 1964. Over-all conclusions about American voting habits are drawn from considerations which include split-ticket voting, incumbent congressmen and the electoral verdict, policy and personality differences between presidential and congressional tickets of the same party, and minor parties.

1966

304 pages 


\section{Political Ideology}

Why the American Common Man Believes What He Does

\section{By Robert E. Lane}

"With this volume Lane consolidates his position as a leader of his generation in the development of a social psychology of political life. . . He has produced our first sustained empirical exploration of the content, sources, and consequences of common political ideologies in psycho-social categories of analysis."-Daniel Lerner, American Sociological Review. ". . a fascinating document that should be read by all of us."-Andrew Hacker, The American Political Science Review. "The author has employed a technique that is first-rate in political science. . . Seldom can the political beliefs of a number of people have been probed in either such breadth or depth . . . may well become a classic of its kind."

$$
320 \text { pages }
$$

-H. B. Mayo, The Journal of Politics

(paper) $\$ 2.95$

\section{Political Life}

Why and How People Get Involved in Politics

\section{By Robert E. Lane}

Political Life is the first comprehensive view of popular participation in American democracy. It summarizes, interprets, and organizes hundreds of research studies on the political process as well as the theoretical literature in the field. “. . . careful and thoughtful ... Lane has produced a study that deserves to be widely used by all students of politics."-Political Science Quarterly

\section{The Nerves Of Government}

\section{Models of Political Communication and Control}

\section{By Karl W. Deutsch}

The Nerves of Government examines the theory that government is more a problem of steering than of power. "Professor Deutsch is one of the important figures in modern political science and this is his most significant book. . . . it needs to be read and reread."--Richard A. Brody, The American Political Science Review 


\section{New-for college courses}

\section{GOVERNMENT IN}

THE UNITED STATES

Webb S. Fiser, State University of New York at Albany;

Stuart Gerry Brown,

University of Hawaii; and

John S. Gibson, Tufts University

Coming in April! This textbook surveys concisely but comprehensively the framework of the American governmental system. Intergovernmental relations are developed as cooperative action between levels of government rather than as compartmentalized treatments of federal, state and local systems. Going beyond discussion of politics, parties, and pressure groups, this book shows how the political process unfolds around concrete policy issues in the context of changing historical developments.

Particular attention is given to such currently important problems as urban renewal, metropolitan areas, poverty, race relations, law enforcement, agriculture, and education. The chapter on science and government and those on the international scene create a sense of student involvement in America's place in the world order.

1967. 803 pages. $\$ 8.50$
PUBLIC

\section{ADMINISTRATION}

John M. Pfiffner, University of

Southern California; and

Robert Presthus,

University of Oregon

Coming in April! A standard for over three decades, this textbook examines administration at all levels of government. The book integrates traditional descriptive-institutional materials of administrative science with behavioral analyses of administration in action. It analyzes such aspects of administration as its historical and institutional framework, the separation of powers, the role of executives (particularly that of the specialist in modern administration), and the problem of obtaining superior talent in government.

Fifth Edition covers decision-making and the data-processing revolution, and discusses the new humanrelations approach-incorporating recent research into group behavior, individual motivation, and leadership dynamics.

5th Ed., 1967. 530 pages. $\$ 8.00$

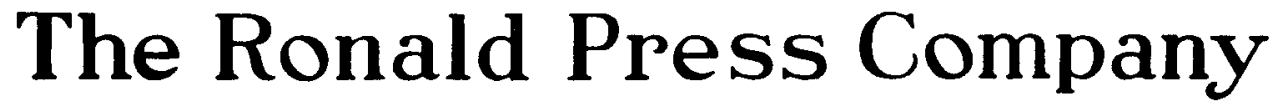




\section{POLITICS AND GOVERNMENT IN THE UNITED STATES}

by EMMETTE S. REDFORD, DAVID B. TRUMAN, ANDREW HACKER ALAN F. WESTIN, and ROBERT C. WOOD

Now in use at over 180 colleges and universities, Politics and Government in the United States presents a full-scale study of the structure and process of American democracy. The book reflects a breadth of knowledge and experience seldom found in a beginning textbook; at the same time, its skillful balance of fact and interpretation, hard analysis, and vigorous style make it an absorbing introduction to American government. " $A n$ excellent work from almost every conceivable point of view."-Henry J. Abraham, University of Pennsylvania. With Instructor's Manual. National Edition: 874 pages, $\$ 8.50$

National, State \& Local Edition: 1,004 pages, $\$ 8.95$

Student Guide by Robert J. Quinlan: Paperbound, 205 pages, $\$ 2.95$

\section{THE CHIEF EXECUTIVE}

\section{by LOUIS KOENIG}

"Mr. Koenig's knowledge of the Presidency and its history, a knowledge that includes both the Constitutional Convention and the first months of the Johnson Administration, is not much short of encyclopedic. In fact, I cannot recall a book on the same subject, nor even those . . . that are required reading in the colleges, that brings together so much information and insight in an organized fashion."-Arnold A. Rogow in Book Week. Text Edition: 435 pages, $\$ 7.50$

\section{VIEWS OF AMERICA}

\section{Edited by ALAN F. WESTIN, JULIAN H. FRANKLIN PAUL E. SIGMUND, and HOWARD R. SWEARER}

Fifty-nine contemporary articles that express the dominant, characteristic opinions of America held in Western Europe, the Communist bloc, and the developing nations of Asia, Africa, and Latin America. A final section explores American reactions to foreign observers and includes recent analyses of the sources and import of foreign commentary. "This is an unusual, I am almost tempted to say unique, book, in that it gathers together what is for the most part difficult to obtain information and opinion on a most important topic, and makes it useful for and relevant to a number of class users."-Russel B. Nye, Michigan State University. Text Edition: Paperbound, 375 pages, $\$ 3.95$

\section{Harcourt, Brace \& World, Inc.}

New York / Chicago / San Francisco / Atlanta 


\section{MAJOR FOREIGN POWERS Fifth Edition \\ by GWENDOLEN M. CARTER and JOHN H. HERZ}

Coming in the spring-a thorough revision and updating of the widely respected text for the basic comparative government course. Major Foreign Powers, Fifth Edition, describes and compares in detail the governments and politics of Great Britain, the Soviet Union, Germany, and France-making frequent reference throughout to relevant aspects of government in the United States and other countries. 720 pages, $\$ 9.50$ (probable). Publication: April, 1967

\section{POLITICAL PATTERNS IN TODAY'S WORLD}

by D. W. BROGAN and DOUGLAS V. VERNEY

Two noted political scientists appraise the operations of democracy and totalitarianism in selected countries-the United States, the United Kingdom, France, Sweden, and the U.S.S.R. "I consider Political Patterns in Today's World the best supplementary reading to a textbook on comparative government."-Nimrod Raphaeli, University of Michigan. Paperbound, 274 pages, $\$ 2.95$

\section{POLITICS IN AFRICA: 7 Cases}

\section{Edited by GWENDOLEN M. CARTER}

"Professor Carter's book offers a lively, highly readable discussion of some of the major current issues in African politics. The case approach is particularly useful for an introductory course, combining as it does a sense for general issues with an appreciation of the circumstances within which each African country, and set of leaders, must operate."-David B. Abernethy, Stanford University. Paperbound, 283 pages, $\$ 3.25$

\section{POLITICS IN THE SOVIET UNION: 7 Cases}

\section{Edited by ALEXANDER DALLIN and ALAN F. WESTIN}

"This collection of essays is remarkable not only for the coverage-everything from literature and art to the military-but for the citations from Soviet writings and the reproductions of Soviet cartoons. The extensive and up-to-date bibliographies are also very valuable. $I$ intend to use this not only for comparative government courses, but also for Russian History."-Mother Jane Miller, San Francisco College for Women. Paperbound, 282 pages, $\$ 3.25$

\section{Harcourt, Brace \& World, Inc.}

New York / Chicago / San Francisco / Atlanta 


\title{
INTERNATIONAL POLITICS IN A REVOLUTIONARY AGE
}

\author{
W. W. KULSKI, Duke University
}

A highly successful text which analyzes the ideological conflicts, discordant national interests and the social and economic factors that underlie today's revolutionary transformations. Close attention is given to the problems of the underdeveloped nations-the "Third World"-and their role in today's power struggle. "Of the perhaps dozen books on the subject that this reviewer has read in the past year, this is by far the most knowledgeable and useful. It can be recommended for student, intellectual and technician alike."-America

650 Pages

\section{THE MAKING OF FOREIGN POLLCY: EAST AND WEST}

KURT LONDON, George Washington University

The author scans the policy machinery of the main protagonists of the East-West conflict-United States, Russia, China, Great Britain and France. Special emphasis is given to the vital roles of intelligence and propaganda in the making and implementation of policy, and the agencies and media are carefully defined. 368 Pages

Paperbound

$\$ 1.95$

\section{THE SOVIET ECONOMY SINCE STALIN}

\section{HARRY SCHWARTZ}

Russia's current economic difficulties and the reasons for them are analyzed by the New York Times' specialist on Russian affairs. The continuing problem of Soviet agriculture and the ouster of Khrushchev are given close attention.

256 Pages

Paperbound

$\$ 1.95$

\section{LA GUARDIA COMES TO POWER: 1933}

ARTHUR MANN, University of Chicago

A distinguished historian examines the significant elements of the election that was a turning point in the history of American urban politics. ". . contains the best account of an urban election we have ever had."-Atlantic Monthly

192 Pages

Paperbound

$\$ 1.95$

\section{THE INTEGRATION OF POLITICAL COMMUNITIES}

KARL W. DEUTSCH, Yale University; PHILIP E. JACOB, HENRY TEUNE, JAMES V. TOSCANO, WILLIAM L. C. WHEATON,

University of Pennsylvania

Integrated political behavior at the metropolitan and international levels is explored in ten essays based on empirical studies in a wide range of fields, including communications, international tensions, planning and regional science, local government, social structure, social psychology and cultural anthropology. 314 Pages

Paperbound

$\$ 1.95$

\section{J. B. LIPPINCOTT COMPANY College Department, East Washington Square,}

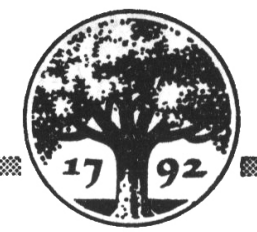

Please mention The American Political Science Review when writing to advertisers 
The Bobbs-Merrill Company, Inc.

and

The Inter-University Case Program, Inc.

announce

\section{Covernmental Reorganizations: A liasebook}

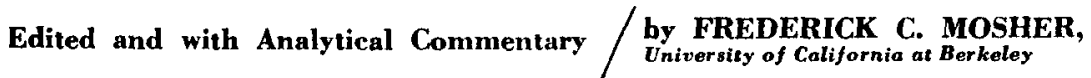

The product of a five-year experimental effort sponsored jointly by the Institute of Governmental Studies at the University of California at Berkeley and the Inter-University Case Program, Inc, this book uses the case study method for systematic research and analysis about the process of administrative reorganization.

A methodological and substantive introduction is followed by 13 case studies, including six not previously published in the ICP series. Part Two of the book is a substantial analysis and commentary on organizations in public administration, the dynamics of organizational change, the participation hypothesis in reorganization, and related factors.

The cases describe a spread of reorganizations-from successful to unsuccessful-in federal, state, and local agencies.

Spring 1967

750 pages

$\$ 12.00$ clothbound An "on approval" title

\section{Some Recent Case Studies in the ICP Series:}

\begin{tabular}{|c|c|c|c|c|}
\hline \multicolumn{2}{|c|}{ ICP No. TITLE } & \multirow{2}{*}{$\begin{array}{l}\text { AUTHOR } \\
\text { Edith T. Carper }\end{array}$} & \multirow{2}{*}{$\begin{array}{l}P P . \\
75\end{array}$} & \multirow{2}{*}{$\begin{array}{c}P R I C E \\
\$ 1.45\end{array}$} \\
\hline 89 & $\begin{array}{l}\text { Reorganization of the U.S. } \\
\text { Public Health Service }\end{array}$ & & & \\
\hline 91 & $\begin{array}{l}\text { Defeating the Leadership's Nominee } \\
\text { in the House Democratic Caucus }\end{array}$ & Rep. Richard W. Bolling & 15 & .50 \\
\hline 95 & $\begin{array}{l}\text { Detroit Experiment: Citizens Plan } \\
\text { for a New High School }\end{array}$ & Roberta S. Sigel & 70 & 2.25 \\
\hline 98 & $\begin{array}{l}\text { The Federal-State Struggle for } \\
\text { Offshore Oil }\end{array}$ & $\begin{array}{l}\text { Hubert Marshall } \\
\text { and Betty Zisk }\end{array}$ & 53 & 1.50 \\
\hline 99 & $\begin{array}{l}\text { Labor Lobbying and Labor Reform: } \\
\text { The Passage of the Landrum-Griffin } \\
\text { Act }\end{array}$ & Samuel C. Patterson & 40 & 1.00 \\
\hline 100 & $\begin{array}{l}\text { The Office of Education and the } \\
\text { Education Act of } 1955\end{array}$ & Stephen K. Bailey & 20 & .50 \\
\hline 101 & Bases in Spain & Theodore J. Lowi & 40 & .75 \\
\hline
\end{tabular}

For these cases, and new catalog, Index and Summary of Case Studies,

The Inter-University Case Program, Inc., listing and describing cases published by ICP from 1948

to the present, write today to:

\section{COLLEGE DIVISION}

THE BOBBS-MERRILL COMPANY. INC. BUBBIDIARY OF HOWARD W, BAMB EO., INC. 4300 WEST O2ND ST. INDIANAPOLIS, INDIANA 46200 


\section{THE STATE OF THE UNION :}

\section{Commentaries on American Democracy}

Edited by Robert B. Dishman, University of New Hampshire. This collection of sixty-four readings on major issues in American life by prominent people in political science, history, economics, politics, education, sociology, and the arts has been organized around key phrases of the Preamble to the Constitution. The editor's essays introduce each subject and discuss the problems and issues involved. There is an additional Topical Table of Contents in the back of the book. 1965. $x$, 546 pages. Paper. $\$ 4.85$

\section{PRESSURE GROUPS IN AMERICAN POLITICS}

Edited by $\boldsymbol{H}$. R. Mahood, Memphis State University. This collection of essays by distinguished writers introduces the student to the important role played by pressure groups in public policy-making and brings to his attention the existence of a group theory of politics. It presents both a theoretical and factual framework for a "group" basis of politics-viewing politics as the activity of different groups in conflict. 1967. $x$, 304 pages. Paper. $\$ 2.75$

\section{DEMOCRACY AND ELITISM : Two Essays with Selected Readings}

By Harry Girvetz, University of California, Santa Barbara. For courses on the "isms" and political philosophy, this book presents an informative symposium on democracy and elitism. Two long essays by the author present clear and reasoned definitions of democracy and elitism. The readings which follow document and expand points made in the first two essays. In summation an Epilogue asks: Do elitist or democratic tendencies now dominate in the United States? 1967. $x i, 349$ pages. Paper. $\$ 3.50$

\section{NEUTRALISM AND DISENGAGEMENT}

Edited by Paul F. Power, University of Cincinnati. This anthology examines the various forms of neutralism and disengagement as they are avowed and practiced by many nations today. The editor has drawn upon government documents, speeches, articles, reports, and excerpts from treatises to represent the different approaches taken to these policies throughout the world. With suggested topics for controlled and library research. 1964, xii, 192 pages. Paper. \$2.50

\section{FRANCE, GERMANY, AND THE WESTERN ALLIANCE:}

\section{A Study of Elite Attitudes on European Integration and World Politics}

By Karl W. Deutsch, Yale University, Lewis J. Edinger, Washington University St. Louis, Roy C. Macridis, Brandeis University, and Richard L. Merritt, Yale University. This study, for courses in international politics or foreign relations, summarizes and discusses elite opinions on such questions as the future of NATO and the Western Alliance, arms control and disarmament, the reunification of Germany, and France after De Gaulle. 1967. xii, 324 pages. Paper. $\$ 2.95$

\section{CHARLES SCRIBNER'S SONS}

\section{COLLEGE DEPARTMENT • 597 FIFTH AVENUE · NEW YORK}




\section{From ST. MARTIN'S}

St. Martin's Series in American Politics:

\section{The Modern Presidency}

\section{Grant McConnell, The University of Chicago}

A coherent exposition of the modern presidency as it has emerged through the long term of American history, and especially as it has been transformed in the years since the Depression.

1967. 128 pages. Paper: $\$ 1.50$

Other books in the Series:

\section{The New Congress}

Stephen K. Bailey, Syracuse University

"This insightful and compact treatment by a sophisticated scholar and practitioner of politics should be a particularly convenient introduction to the subject for both laymen and undergraduates. It contains some points which may be instructive to the more advanced and experienced reader as well. Well written throughout."

-Herman Somers, Princeton University 1966. 128 pages. Paper: $\$ 1.50$

\section{Political Parties in the United States}

Allen P. Sindler, Cornell University

"This is a delightful book to be read both by the specialist and by the non-specialist in the field of politics. Chapter IV on the general characteristics of American National Parties is especially penetrating and thought-provoking.

-James A. Gathings, Bucknell University 1966. 128 pages. Paper: $\$ 1.50$

\section{The Convention and the Constitution}

The Political Ideas of the Founding Fathers

David G. Smith, Swarthmore College

"Places the great issues of the 1787 Constitutional Convention in the perspective of the political theories of the drafters-an illuminating volume."

-C. Edwin Gilmour, Grinnell College 1965. 128 pages. Paper: $\$ 1.75$

To be published:

Political Theory George Kateb, Amherst College Spring 1968. Paper: $\$ 1.50$ tent.
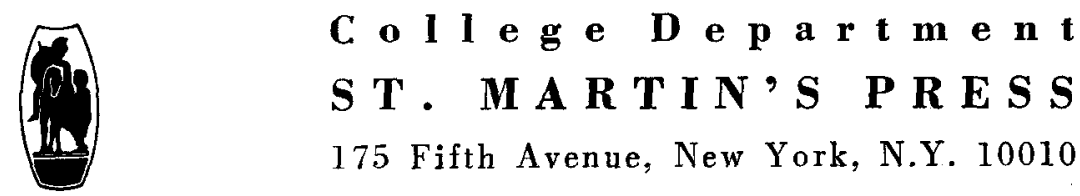

Please mention The American Political Science Review when writing to advertisers 


\section{INCENTIVES \\ to thoughtful and spirited discussioms}

\section{STUDILS IN HISTORY AND POLITICS}

Each volume in this distinctive series combines thematic organization, primary sources, scholarly interpretive essays along with editorial introductions and comments in order to provide valuable historical-political perspectives on topics in

- American History

- European History
- American Politics

- Comparative Politics

\section{Latest Titles}

BRITISH POLITICS-

People, Parties and Parliament

ANTHONY KING, University of Essex
SOLDIERS AND STATES-

Civil-Military Relations in Modern Europe DAVID B. RALSTON, Massachusetts Institute of Technology

\section{Already Available}

\section{CHURCH AND STATE} IN AMERICAN HISTORY JOHN F. WILSON, Princeton University

\section{RUSSIA AND THE WEST-} from Peter to Khrushchev

L. JAY OLIVA, New York University
THE DEVELOPMENT OF THE COMMUNIST BLOC

ROGER W. PETHYBRIDGE, University College, Swansea

\section{PROBLEMS IN AMERICAN CIVILIZATION}

- THE DEBATE OVER THERMONUCLEAR STRATEGY

- THE MEANING OF McCARTHYISM

- INTERVENTION, 1917:

Why America Fought
- THE WAR OF 1812:

Past Justifications and Present Interpretations

\section{- PEARL HARBOR:}

Roosevelt and the Coming of the War, Revised Edition

All volumes paperbound

\section{C. HEATH AND COMIPANY college department}

Home Office: Boston, Mass. 02116 Sales Offices: Englewood, N.J. 07631

Indianapolis, Ind. 46219 San Francisco, Calif. 94105 Atlanta, Ga, 30324

Dallas, Tex. 75247 London W.C. I Toronto 2-B 


\section{The New Inter-Nation Simulation Kit}

\section{for teaching and research has been developed}

\section{by Harold Guetzkow, Northwestern University Cleo H. Cherryholmes, Michigan State University}

SRA, long a leader in innovation for education, has published INSKit ${ }^{\text {TM }}$ to bring new dimensions to teaching and research in the social sciences. The model used is the result of years of continuing research and refinement at Northwestern University.

INSKit provides, besides the basic model, details on conduct and variations of the simulation and line-by-line directions for the several forms used to record, report, and calculate the consequences of the economic, military, and political decisions.

With INSKit, you need only students, time, and space to open the full potentialities of inter-nation simulation ... . and at far less cost than you would need to prepare your own model and materials.

Write for prices or for a visit from an SRA College Associate.

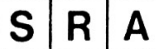

Science Research Associates, Inc. 259 E. Erie St., Chicago, III. 60611

A Subsidiary of IBM

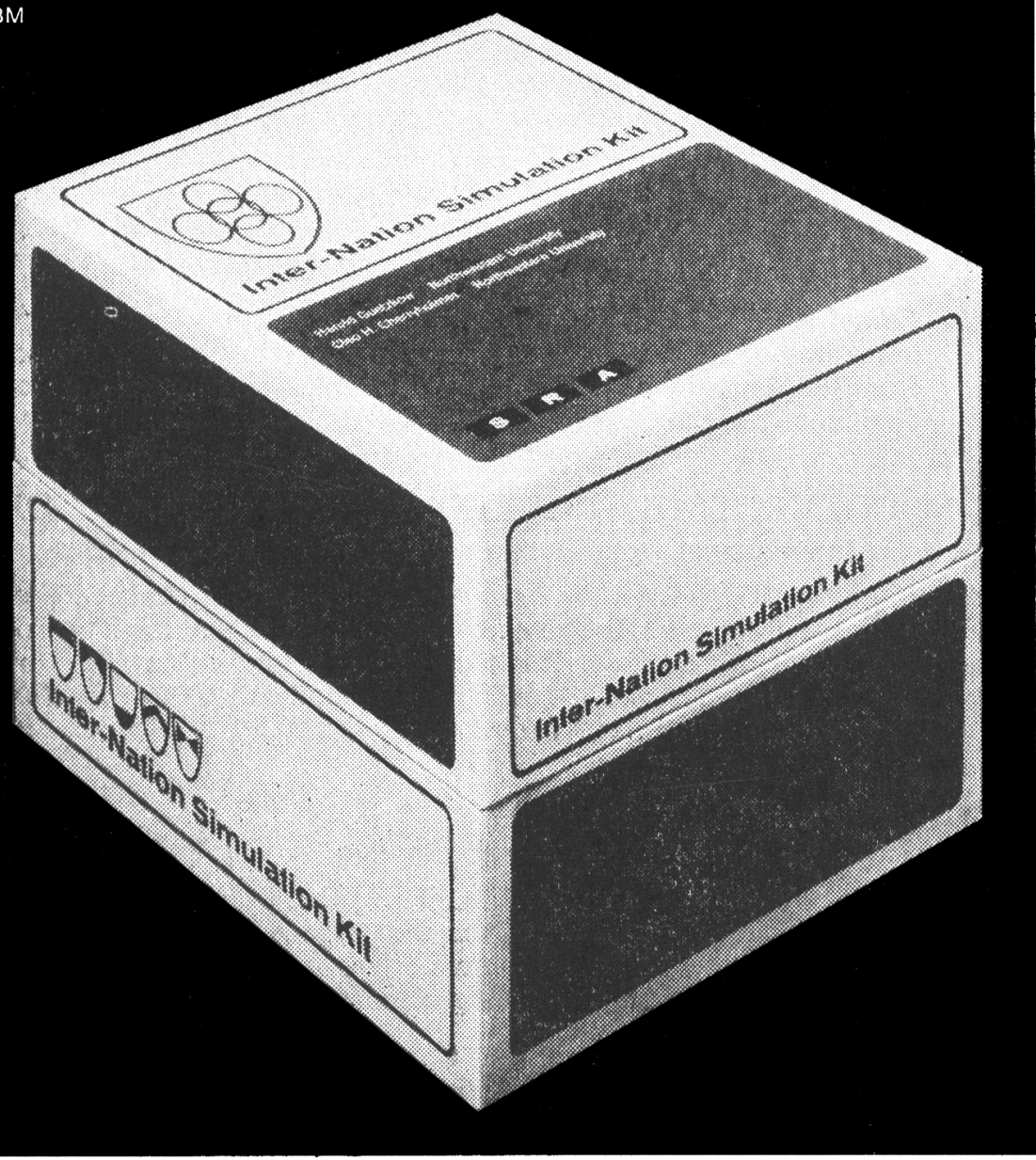

Please mention The American Political Science Review when writing to advertisers 


\section{Now is the time for all good political scientists-}

\section{INTERNATIONAL POLITICS SINCE WORLD WAR II: A Short History}

By CHARLES L. ROBERTSON, Smith College. INTERNATIONAL POLITICS SINCE WORLD WAR II combines a fairly detailed summary of international events and crises since the war with an overview of broad changes in the political pattern of the world. It takes as a starting point the world of sovereign nation-states that developed in previous centuries. It then shows how recent events result from the combination of older patterns of politics with new developments in mass communications and mass ideologies, increases in population, the rise to power of new major states and the transformation of old empires into a large number of new successor states, and finally, the development of new weapons. 1966.385 pages. Cloth: \$6.95. Paper: \$3.95.

\section{POLITICAL DEVELOPMENT AND SOCIAL CHANGE}

Edited by JASON L. FINKLE, The University of Michigan; and RICHARD W. GABLE, University of California, Davis. This reader in political sociology provides a systems approach and a conceptual framework for analyzing the contemporary process of political development and its relationship to other societal transformations. 1966.599 pages. $\$ 8.95$.

\section{METROPOLIS ON THE MOVE: Geographers Look at Urban Sprawl}

Edited by JEAN GOTTMANN, Ecole des Hautes Etudes (Sorbonne); and ROBERT A. HARPER, Southern Illinois University. Considers the form, forces, and pressures created by urban sprawl, examines its impact upon the functioning of the city, and offers an alternative for the future. 1967. 203 pages. Cloth: $\$ 6.50$. Paper: $\$ 3.45$.

\section{CHINESE SOCIETY UNDER COMMUNISM: A Reader}

Edited by WILLIAM T. LIU, University of Notre Dame. Emphasizes the control apparatus of Chinese society and the various institutional consequences of control from the dynastic periods, through the transitional interlude, to the contemporary Communist regime. 1967. 496 pages. Cloth: \$8.50. Paper: \$5.50.

\section{FROM COLLECTIVE SECURITY TO PREVENTIVE DIPLOMACY}

\section{Readings in International Organization and the Maintenance of Peace}

Edited by JOEL LARUS, Brandeis University. "This collection of writings and documents constitutes a useful and original approach to the study of contemporary international organization. It is particularly helpful to have in a handy form some of the actual documents."-Lincoln P. Bloomfield, Center for International Studies, Massachusetts Institute of Technology. 1965. 556 pages. Cloth: \$6.95. Paper: $\$ 4.95$.

\section{SOCIAL CHANGE: The Colonial Situation}

Edited by IMMANUEL WALLERSTEIN, Columbia University. A comparative and inter-disciplinary approach to the process of change in colonial societies within a world context of modernization. "This is a valuable reference work for anyone seriously interested in developing nations."-Current History. 1966.674 pages. $\$ 9.50$. 


\section{- to make sure they haven't missed these important Wiley publications}

\section{ARMS CONTROL AND THE ATLANTIC ALLIANCE}

By KARL W. DEUTSCH, Yale University. Based on the results of a major research effort on the acceptability of disarmament and arms control measures in the European political environment, this is the first book to test the judgments of scholars and political analysts against verifiable data. Focusing on France and Germany as the key countries of Europe, it combines five streams of evidence: intensive elite opinion surveys; mass opinion data; content analysis of major newspapers; quantitative data about the actual social and economic behavior of countries and peoples; and the historic and diplomatic record. 1967. Approx. 184 pages. Prob. $\$ 5.95$.

\section{ELECTIONS AND THE POLITICAL ORDER}

By ANGUS CAMPBELL, PHILIP E. CONVERSE, WARREN E. MILLER, and DONALD E. STOKES, all at the Survey Research Center, The University of Michigan. In many ways a successor to THE AMERICAN VOTER by the same authors, ELECTIONS AND THE POLITICAL ORDER expresses better than any book yet written the profound shift of electoral research from problems of individual behavior to the problems of a wider political order. 1966.385 pages. $\$ 8.75$.

\section{SIMULATION AND NATIONAL DEVELOPMENT}

By ANDREW M. SCOTT, University of North Carolina; with WILLIAM A. LUCAS and TRUDI M. LUCAS. This book examines the research potential of one kind of simulation for the investigation of social change in modernizing societies. It demonstrates ways that the central features of entire social, political, and economic systems can be simulated. By simplifying the complex processes of development, by compressing the time required for their evolution, and by building a working model of them, the observer can learn about the larger processes by studying the miniature. 1966.177 pages. $\$ 5.95$.

\section{JUSTICE WITHOUT TRIAL}

\section{Law Enforcement in Democratic Society}

By JEROME H. SKOLNICK, University of California, Berkeley. "To my mind it is by far the best thing that has been done on the police and is a must for anyone who attempts to understand the current controversy over the relation between individual rights and the protection of society. Mr. Skolnick has not only done an able job of research, but has presented his material in a well-written and fascinating form. This study should be a model for those it will inspire over the next generation."-John Kaplan, Stanford University School of Law. 1966. 279 pages. $\$ 7.95$.

now available in paperback...

HUMAN NATURE IN POLITICS

By JAMES C. DAVIES, University of Oregon. 1963.403 pages. $\quad$ Paper: $\$ 4.95$. (Cloth: \$7.95.)

\section{THE DYNAMICS OF THE AMERICAN PRESIDENCY}

Compiled and edited by DONALD BRUCE JOHNSON, University of Iowa; and JACK L. WALKER, The University of Michigan. 1964.355 pages. Paper: \$4.95. (Cloth: \$7.95.

605 Third Avenue, New York, N.Y. 10016

Please mention The AMerican Polttical. ScIence Review when writing to advertisers 
"An achievement in historiography ...also in political science."

-David Riesman, Commentary

\section{"A classic" -Times Literary Supplement}

A new introduction, written from the perspective of the nineteen sixties, and an enlarged bibliography bring up-to-date this classic study of twentieth century politics. The extended essay which introduces this new edition takes into account Stalin's plans during the last years of his life as well as a consideration of the significance of the Chinese revolution and the present crisis which had just started when this edition went to press.

Photo by Fred Steln

\section{Hannah Arendt}

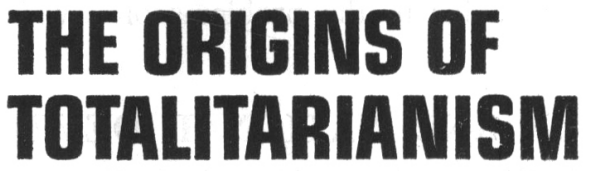

\$8.75 四 HARCOURT, BRACE \& WORLD

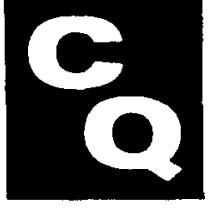

CQ GUIDE TO CURRENT

AMERICAN GOVERNMENT

... recent significant developments in American Government

120 pages, $81 / 2 " \times 11 "$

Fall edition in print late August 1967

(Spring 1967 edition available now)

\section{REPRESENTATION AND APPORTIONMENT}

$\therefore$ response of the nation to Supreme Court's decisions

August 1966, 96 pages, $81 / 2$ "XI1"

\section{HOUSING A NATION}

$\therefore$. federal policy from 1945 through 1965 crea. tion of Department of Housing and Urban Development

March 1966, 96 pages, $81 / 2 " \times 11 "$
$\$ 2.50$

$\$ 2.50$

$\$ 2.00$

Examination copies ayailable to faculty members upon request
POLITICS IN AMERICA 1945-1966

... elections since 1945 reviewed and related to national and international events; data on results; election law developments

About May 1967, 124 pages, 81/2"x11" $\$ 2.50$

(1945-1964 edition avallable now)

\section{REVOLUTION IN CIVIL RIGHTS}

... developments since 1945 through 1965 Voting Rights Act

September 1965 , 96 pages, 81/2"x11".

(To be updated through 1966 about June 1967)

\section{LEGISLATORS AND THE LOBBYISTS}

... how Congress is pressured and by whom; the military-industrial lobby; case studies of legislation

August 1965,80 pages, $81 / 2 " \times 11^{\prime \prime}$

$\$ 2.50$

\section{EDUCATION DEPARTMENT \\ CONGRESSIONAL QUARTERLY SERVICE 1735 K Street, N.W., Washington, D. C. 20006}




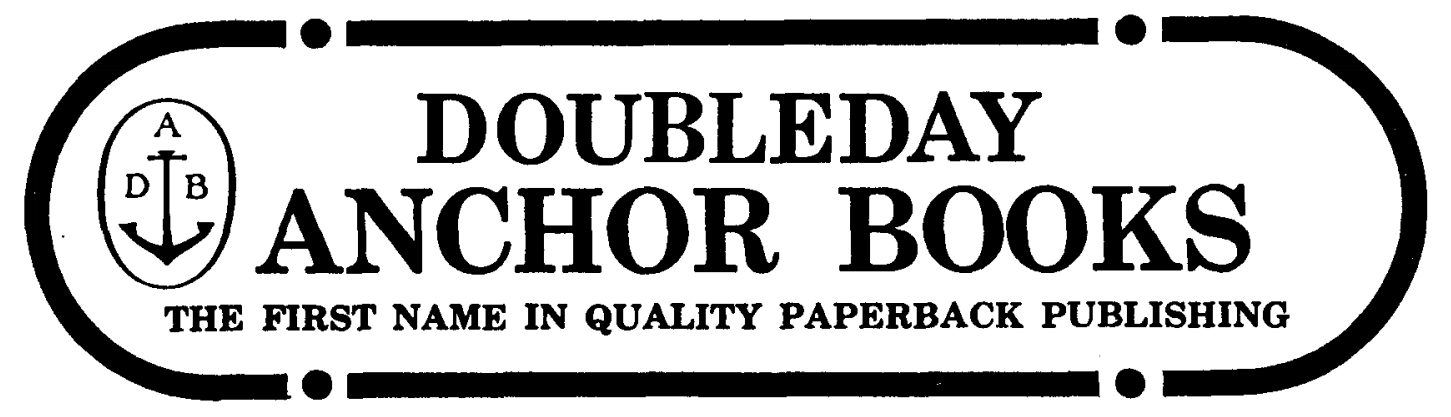

FROM RACE RIOT TO SIT-IN: 1919 and the 1960s

A Study in the Connections Between Conflict and Violence

Arthur 1. Waskow

An analysis of the race riots of 1919 and the recent movement of "creative disorder," offering entirely new evidence and new "inventions" by which racial justice can be achieved without national catastrophe. "Brilliant and creative."-Washington Star

$\$ 1.45$

\section{THE GOVERNMENT AND POLITICS OF INDIA}

\section{W. H. Morris-Jones}

This study of the operation of political institutions in independent India concentrates on how local loyalties, the caste system, overpopulation, language barriers, and other factors influence the formal framework of government.

$\$ 1.25$

\section{URBAN RENEWAL: PEOPLe, POLITICS AND PLANNING}

Edited by Jewel Bellush and Murray Hausknecht

This reader on the political controversies and sociological realities of revitalizing the American city deals with such topics as constitutional questions, slum clearance, leadership problems, citizen participation, and the effects of public housing. An Anchor Original.

$\$ 1.95$

\section{THE RADICAL PAPERS}

Edited with an Introduction by Irving Howe

Michael Harrington, Bayard Rustin, Harvey Swados, Paul Goodman, Christopher Jencks, Daniel Bell, George Lichtheim, and fifteen other Americans call for radical social reforms as they write on education, urban renewal, civil rights, and poverty.

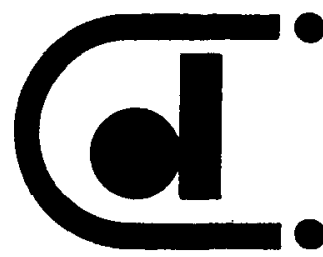

DOUBLEDAY \& COMPANY, INC. Garden City, New York

Our Laidlaw division, River Forest, Illinois, serves the textbook needs of today's schools. 


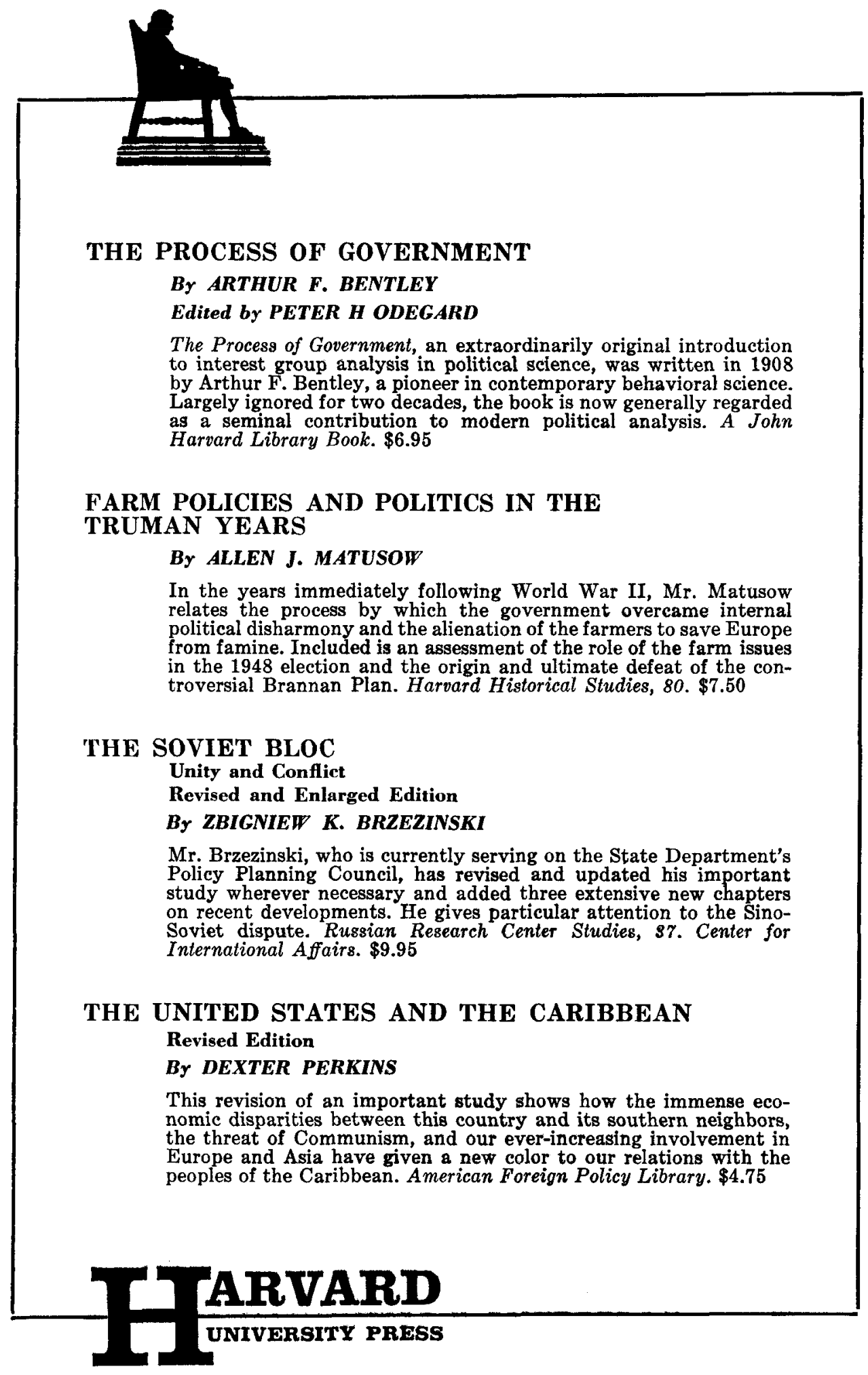

Please mention The Amekican Porltcal Scrence Review when uriting to advertisers 


\section{LOOKING FOR A BOOK PUBLISHER?}

It is no secret that publication is regarded as the foundation stone of a scholar's career. In order to gain recognition, prestige, and advancement, the scholar must seek publication.

Here at Exposition Press, we offer scholars a complete publishing service, under our special academic imprint, "Exposition-University Books." Though the proportion of scholarly publications in the lists of the trade houses is shrinking, due to economic pressures, many of our recent titles in the academic fields have gained popular reviews, professional recognition and steady sales. These books are the result of a publishing plan that is bringing a steady flow of scholarly writers to Exposition Press. They reflect the high editorial standards and quality of design and production which have won the respect of libraries, schools, booksellers and critics. Ask for free catalogs.

FREE! The behind-the-scenes story of book publishing revealed in two fact-filled, illustrated brochures, containing a detailed description for our subsidy plan includ. ing a breakdown of contract terms and typical costs (in print for the first time). Copies are available on request. Your inquiries and manuscripts are invited. An editorial appraisal will be furnished promptly without obligation. References upon request.

Please write to Dept. 93C

EXPOSITION PRESS, Main Office, 386 Park Ave. So., New York 16, N.Y. California office: 9172 Sunset Blvd., Los Angeles 69, Calif.

\section{WORLD POLITICS \\ A Quarterly Journal on International Relations \\ Under the Editorial Sponsorship of the \\ CENTER OF INTERNATIONAL STUDIES}

Vol. XIX

April 1967

No. 3

CONTENTS

Containment in Asia Reconsidered $\ldots \ldots \ldots \ldots \ldots \ldots \ldots \ldots \ldots \ldots \ldots \ldots \ldots \ldots \ldots \ldots \ldots \ldots \ldots \ldots$ David P. Mozingo

On the Effects of International Economic Sanctions, With Examples

from the Case of Rhodesia

.. Johan Galtung

French Strategy Emergent: General André Beaufre-A Critique ................ Edward Y. KolodzIEJ

The Political Order and the Burden of External Relations ..................... PAUL. YAMmOND

Social Science Research Abroad: Problems and Remedies

KIAUS KNORK

Research Note

Political Integration and Political Stability: A Hypothesis

C. Claude Are

Review Articles

The Communist Phoenix and the Indonesian Garuda $\ldots \ldots \ldots \ldots \ldots \ldots \ldots \ldots \ldots \ldots$. $\ldots \ldots$ Wuth Wilcner

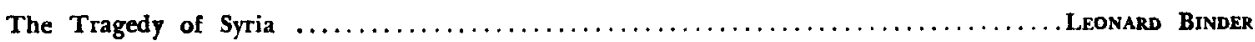

Subscriptions, $\$ 7.50$ a year (two years, \$12.50), single copies $\$ 2.50$

WORLD POLITICS

Corwin Hall, Princeton, New Jersey 08540

Please mention The American Potiticat Science Review when writing to advertisers 


\section{SPRING，1967，TEXTS FROM \\ DO D D \\ MEA D}

\section{COMPARATIVE \\ GOVERNMENT \\ AND POLITICS}

by DELL G. HITCHNER and CAROL. LEVINE

The extraordinary success of Modern Government: A Survey of Political Science, Second Edition, 1965, by Dell G. Hitchner and William H. Harbold, The University of Washington, has led Professor Hitchner and Carol Levine to prepare a derivative paperback designed for the comparative government course. It may be used with the various short books devoted to the government of a single country that are commonly used in that course. The perspective is entirely comparative and analytical. The authors refer to a wide range of governments, especially the developing countries. Included is a treatment of communist governments and politics.

April approx. 250 pages paperback tentative price $\$ 2.95$

\section{THE \\ SELECTIVE \\ SERVICE \\ ACT}

\section{A CASE STUDY OF THE GOVERNMENTAL PROCESS}

by CLYDE E. JACOBS and JOHN F. GALLAGHER

The authors offer a case study of the legislative enactment of the Selective Service Act of 1948 and of executive implementation and judicial interpretation of this legislation. The study is designed to show the student how each of the three branches of government participates in the policy-making process. It is designed for use in introductory courses in American government and in advanced courses in American government and in public policy formulation. Clyde E. Jacobs is at the University of California, Davis, and John F. Gallagher is a member of the commission on the New York State Constitutional Convention.

April approx. 200 pages paperback tentative price $\$ 2.50$

\section{DODD, MEAD \& COMPANY, INC.}

79 Madison Avenue, New York, N.Y. 10016

IN CANADA: 25 Hollinger Road, Toronto 16, Ontario 


\title{
CROWELL STUDIES IN POLLTICAL SCIENCE
}

The titles in this new series focus upon topics that are crucial to the understanding of political processes. The volumes, which are primarily analytical, have been designed for use by undergraduates; they are clearly and succinctly written, and they make use of the most recent research and data. Teachers of Political Science should find the books in this series valuable for supplementary assignments in survey courses as well as courses on the advanced level.

\section{THE AMERICAN POLITICAL SYSTEM IN TRANSITION}

\author{
Harry Lazer, City College of New York
}

How adaptable has the American political system, conceived in the eighteenth century, been to the dramatic changes of the last two hundred years? How well has our method of government adjusted to the shift from a rural agricultural society to an urban industrial one? This volume attempts to find the answers to these questions by analyzing the impact of social and economic change upon the institutions of our government. Mr. Lazer first traces the historical development of these changes, noting the effects they have had on the executive, legislative, and judicial branches of government. He then asks this important question: In what ways have the branches of government succeeded in rising to the challenges of the twentieth century and in what ways have they failed?

April, 1967

256 pages

about $\$ 2.50$

\section{PRESIDENTIAL PRIMARIES}

\author{
Road to the White House \\ James W. Davis, Central Michigan University
}

In the twentieth century the Presidency has emerged as the keystone of the American system of government. This raises a crucial question for students of politics: By what process does the victorious candidate reach the White House? This book analyzes the first essential step in this process-the winning of the presidential nomination. Mr. Davis contends that in the past three decades the successful candidates have laid the groundwork for victory in the presidential primaries. By using the primaries to bypass state leaders and party professionals supporting other candidates, the eventual nominees have placed the choice of the presidential nomination in the hands of the voters in the primary states, even though less than a third of the states use the primary system. Thus, the national conventions have tended to become ratifying bodies rather than deliberative assemblies convened to choose the "best qualified" candidates. To support this thesis, the author has, in this volume, undertaken the first comprehensive study of the primary system since 1926.

April, 1967

304 pages

about $\$ 2.50$

\section{AMERICAN FEDERALISM A View from the States \\ Daniel J. Elazar, Temple Universiły}

Though federalism is a concept integral to the American system of Government, it is, nonetheless, not often fully understood. At a time when national programs in such important areas as education, civil rights, welfare, and public improvements carry strong implications for the federal system, it is essential that students of government know what federalism is, and how it relates to today's politics. This penetrating analysis views the federal system from the vantage point of the states, the basic components of the federal union.

1966

288 pages

\section{THOMAS Y. CROWELL COMPANY \\ 201 Park Avenue South New York 10003 \\ Please mention Thr American Political Scinnce Review when weriting to advertisers}




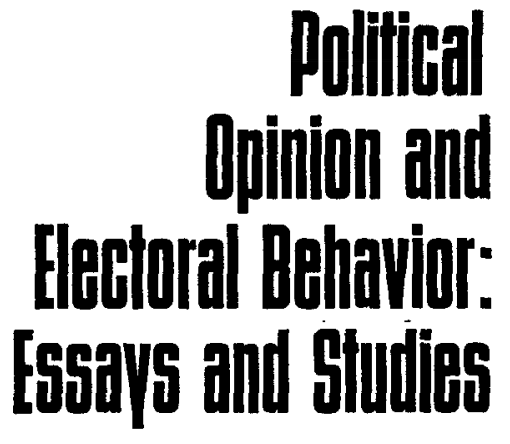

Congress in Crisis:

Polititics and

Congrestional Reterm

NEW: Edited by Edward Dreyer, San Diego State College, and Walter Rosenbaum, University of Florida. 1966.

506 pages. $6 \times 9$. Paperbound.

"A collection of almost uniformly important articles. Tied together with interpretative comments of conceptual clarity and unity - a very rare accomplishment for a book of readings."-Bernard C. Hennessy, Pennsylvania State University

NEW: By Roger Davidson and David Kovenock, Dartmouth College, and Michael O'Leary, Syracuse University. 1966. 224 pages. $5 \% / 8 \times 83 \%$. Paperbound.

“...this manuscript is the most sensible discussion of Congressional reform I have read. At last someone has sought to make the value judgments underlying various reform proposals explicit, and to clarify systematically the alternative roles Congress might play in the American political system." -Donald R. Matthews, University of North Carolina

Just published:

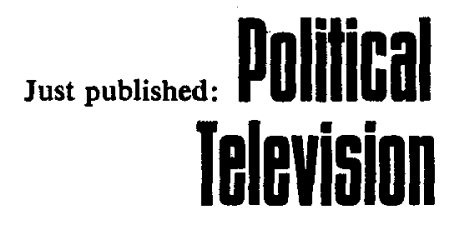

Politifial

Also of interest:
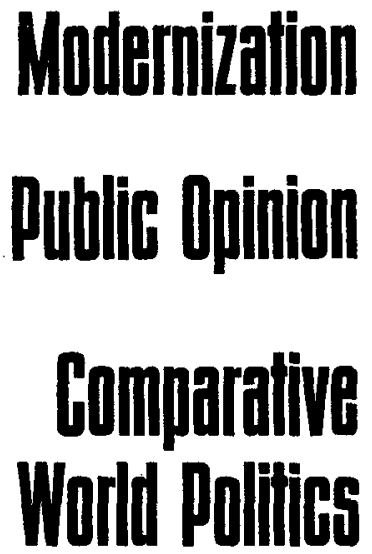

By Bernard Rubin, Boston University. 1967. 208 pages. $6 \times 9$. Paperbound.

Readings in Comparative Political Change edited by Claude Welch, SUNY at Buffalo. 1967. 384 pages. $6 \times 9$. Paperbound.

By Bernard Hennessy, Pennsylvania State University. 1965.384 pages. $6 \times 9$. Clothbound.

Readings in Western and Premodern Nonwestern International Relations edited by Joel Larus, New York University. 1964. $6 \times 9.286$ pages. Paperbound.

For review copies write to box APSR-1 


\section{A POLITICAL HISTORY} OF POSTWAR ITALY

The author, Professor of Political Science at the University of Connecticut, analyzes the major political and economic events of the past two decades, including the establishment of Italy's first Center-Left government and the "economic miracle" that has transformed northern and central Italy. $\mathrm{He}$ also explores why-despite improved economic conditions-the political stability of the country remains precarious. 252 pp. $\$ 6.00$ clothbound

\section{THE POLITICS OF ITALIAN FOREIGN POLICY}

This penetrating book undertakes to show that the key objective of Italian foreign policy is to protect the domestic social structure. "A useful, worth-while study."-Library Journal. 190 pp. tables, index. $\$ 5.00$ clothbound

\section{FrEDERICK A. PRAEGer, Publishers}

111 Fourth Avenue, New York, N.Y. 10003

\section{ANTI-FEDERALISTS VERSUS FEDERALISTS}

Selected Documents

Edited by John D. Lewis, Oberlin College

Documents concerning the famous debate over the adoption of the Constitution in 1787-1788. The arguments of the defenders of the Constitution are drawn chiefly, but not exclusively, from The Federalist, by Hamilton, Madison, and Jay. The anti-Federalist arguments are from various sources.

Approx. $320 \mathrm{pp}$.

paper approx. \$3.50

GARRISONS AND GOVERNMENT: Politics and the Military in New States

Edited by Wilson C. McWilliams, Oberlin College

A survey of the political role of military organizations in developing countries, set in a broad comparative and historical framework, designed to help the reader understand the influence of the military on politics in new and old nations.

Approx. $330 \mathrm{pp}$.

paper approx. $\$ \mathbf{2 . 5 0}$

\section{THE LAW OF THE POOR}

Edited by Jacobus tenBroek, University of California, Berkeley and the Editors of California Law Review

The purpose of this symposium was to provide a critical review of the rules and procedures, doctrines and presuppositions of the law of the poor. Sponsored by the Center for the Study of Law and Society, it included scholars from the fields of law, social science, and social work.

$704 \mathrm{pp}$.

paper $\$ 4.95$, cloth $\$ 10.00$ 


\title{
MARX'S ECONOMIC PREDICTIONS
}

\section{by Fred $M$. Gottheil}

During the course of his creative years (1843-83), Marx produced a large quantity of economic, political, and historical books, essays, pamphlets, addresses, and correspondence. Dispersed among these writings were many prophecies, both abstract and specific. Marx's Economic Predictions evaluates over 150 of his predictions as logical derivatives of his theoretical system.

$$
x v+216 \text { pages } \$ 7.50
$$

\section{THE SUSPECT AND SOCIETY}

Criminal Procedure and Converging Constitutional Doctrines

\section{by Walter V. Schaefer}

In The Suspect and Society, the author deals with the legal problems that cluster about police interrogation of persons suspected of having committed crimes; he considers the constitutional doctrines that bear upon this practice as it has been conducted in the past; and he discusses the model code of procedure advanced by the American Law Institute. The proposals offered in this book should be of interest to everyone concerned with the application of our constitutional ideals to our legal institutions.

$$
100 \text { pages } \$ 3.50
$$

\section{PERSPECTIVES ON THE COURT}

\section{by Max Freedman, William M. Beaney, and Eugene V. Rostow}

During the past twenty years the Supreme Court has been involved in reformulating our fundamental law as it relates to civil rights, separation of church and state, reapportionment, and criminal procedures. Here, the Court's performance is viewed by three eminent men from the vantage points of journalism, political science, and law.

120 pages

$\$ 3.50$

\section{APPROACHES TO COMPARATIVE AND INTERNATIONAL POLITICS}

\section{R. Barry Farrell, editor}

In this volume, twelve internationally respected political scientists analyze the relationship between national and international politics. These scholars are Karl W. Deutsch, James N. Rosenau, Carl J. Friedrich, George I. Blanksten, Pablo González Casanova, Norton E. Long, R. Barry Farrell, Vernon V. Aspaturian, Roland Young, Chadwick F. Alger, Raoul Naroll, and Oliver Benson.

$$
368 \text { pages cloth, } \$ 9.95 \text { paper, } \$ 3.95
$$

\section{NORTHWESTERN UNIVERSITY PRESS}

\author{
Evanston, Illinois
}




\section{HOUGHTON MIFFLIN PAPERBACKS IN CONTEMPORARY GOVERNMENT ... .}

THE GOVERNMENT OF REPUBLICAN ITALY, Second Edition. John Clarke Adams and Paolo Barile. 251 pages, 1966, $\$ 2.50$.

BRITISH PARLIAMEN'TARY DEMOCRACY, Second Edition. Sydney D. Bailey. 281 pages, 1966 Impression, $\$ 2.50$.

THE FEDERAL GOVERNMENT OF SWITZERLAND. George Arthur Codding, Jr. 174 pages, 1965 Impression, $\$ 2.50$.

THE POLITICAL SYSTEM OF CHILE. Frederico G. Gil. 323 pages, 1966, $\$ 2.95$.

GOVERNMENT AND POLITICS IN ISRAEL. Oscar Kraines. 246 pages, $1961, \$ 2.50$.

CONTEMPORARY GOVERNMENT OF JAPAN. Theodore McNelly. 228 pages, 1963, $\$ 2.50$.

GOVERNMENT AND POLITICS IN MALAYSIA. R. S. Milne. 259 pages, 1967, $\$ 2.75$.

THE MEXICAN POLITICAL SYSTEM. L. Vincent Padgett. 244 pages, $1966, \$ 2.75$.

THE INDIAN POLITICAL SYSTEM. Norman D. Palmer. 277 pages, 1961, $\$ 2.50$.

CONTEMPORARY GOVERNMENT OF GERMANY. EImer Plischke. 248 pages, 1964 Impression, \$2.25.

THE POLITICAL SYSTEM OF PAKISTAN. Khalid B. Sayeed. About 300 pages, Spring 1967.

SOUTH VIETNAM: Nation Under Stress. Robert Scigliano. 227 pages, $1963, \$ 2.50$.

NORWEGIAN DEMOCRACY. James A. Storing. 246 pages, $1963, \$ 2.50$.

\section{HOUGHTON MIFFLIN}

Boston Allanta Dallas Geneva, III. New York Palo Alto 


\section{THE JAPANESE COMMUNIST MOVEMENT, 1920-1966}

\section{Robert A. Scalapino}

In this authoritative account of the evolution of the Japanese Communist Party from its beginnings nearly half a century ago to its present situation, an acute student of Asian society provides an arresting portrait of a political party that, by orthodox Marxist criteria, should have risen to first importance but never did. While according most attention to domestic developments both within and outside the party, Mr. Scalapino also relates them meaningfully to their international context. His account of the inability of the party to draw lasting political advantage from the opportunities that have presented themselves over the years is notable for its grasp of Japanese political realities. Drawing on a wide range of primary sources, written with a sense of the dramatic qualities of the story, and demonstrating a mastery of its subject, this book represents a milestone in the study of Asian politics.

A publication of the Center for Japanese and Korean Siudies

$\$ 6.50$

\section{POLITICAL PARTICIPATION IN COMMUNIST CHINA}

\section{James R. Townsend}

The first systematic study of mass political participation in Communist China, a crucial aspect of its political development. Mr. Townsend discusses the Chinese Communist style of participation, relating it to historical precedents in the pre-Communist setting, Soviet Marxism, and the experience of the Chinese Communist Party. He then considers how the Chinese Communist concept of participation has been implemented since the establishment of the present government.

A publication of the Center for Chinese Studies.

\section{CALIFORNIA SLAVIC STUDIES: Volume IV}

\section{N. V. Riasanovsky and Gleb Struve, Editors}

This series presents articles broadly representative of the field of Slavic and East European affairs. Vol. IV contains articles by Kathryn B. Feuer, Waclaw Lednicki, Edward Chmielewski, Nicholas V. Riasanovsky, Xenia Gasiorowska, George Gomori, and Henrik Birnbaum.

$\$ 5.00$

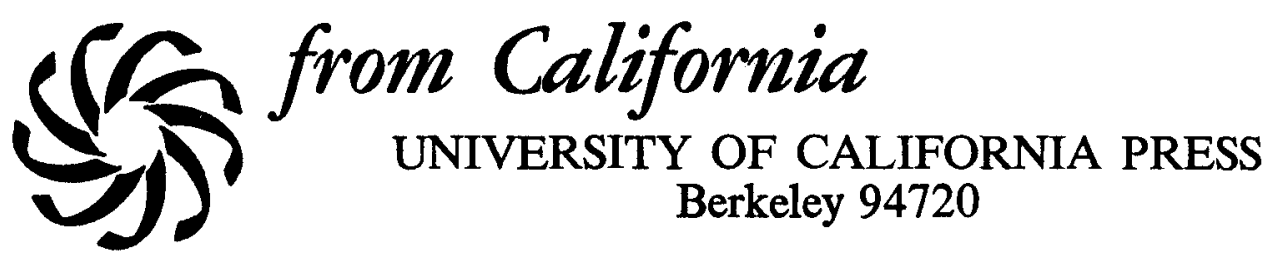

Please mention The American Poitical Science Rrview tehcn witing to advertisers 


\section{To supplement the series:}

Readings in Modern Political Analysis, Edited by Robert A. Dahl, Yale University, and Deane E. Neubauer, University of California, Irvine

PUBLISHED TITLES IN THE SERIES

The Age of IDEOLOGY, by Frederick M. Watkins, Yale University

The American Party System and the American People, by Fred I. Greenstein, Wesleyan University

Congress and the Presidency, by Nelson W. Polsby, Wesleyan University

Modern Political Analysis, by Robert A. Dahl, Yale University

Perspectives in Constitutional Law, by Charles L. Black, Jr., Yale University

Politics and Policies in State and Local Governments, by Herbert Kaufman, Yale University

Public Opinion, by Robert E. Lane, Yale University and David O. Sears, University of California, Los Angeles

To supplement the series:

Readings in American Political Behavior, Edited by Raymond E. Wolfinger, Stanford University

Each of the volumes in the series is designed in a uniform 6" $\times 9$ " format, approx. 128 pp., paperbound $\$ 1.75$, cloth $\$ 4.50$

\section{COMPARATIVE ASIAN GOVERNMENT SERIES}

\section{Edited by Robert E. Ward and Roy C. Macridis}

This series provides a comparative and functionally oriented analysis of twentyone contemporary Asian political systems including Japan, India, the Chinese People's Republic, eight Southeast Asian and ten Southwest Asian countries.

FOR 1967 PUBLICATION:

India's Political System, Richard L. Park, University of Michigan. This book provides an introduction to the modern political system of India with stress given to the historical, social, and economic background, plus an emphasis in analysis given to political behavior. Fall 1967

JaPAn's Political System, Robert E. Ward, University of Michigan. Ward views the Japanese political system as a distinguishable but interrelated segment of the total Japanese social system and goes to unusual pains to clarify the ways in which Japanese politics are shaped and affected by such factors as social structure, values, history, and economics. May 1967

Southeast Asia's Political Systems, Lucian W. Pye, Massachusetts Institute of Technology. The principal focus of this study is on comparative patterns of modernization in Southeast Asia. Southeast Asia in this sense is seen as providing a laboratory for distinguishing different patterns of modernization. June 1967

Southwest Asia's Political Systems, Dankwart A. Rustow, Columbia University. This book aims to provide an accurate, objective, and up-to-date description and comparative analysis of the Southwest Asian political systems in accordance with an organizational framework that will make these data meaningful for comparing the Southwest Asian political systems to other political systems, including our own. Forthcoming

China's Political Systems, by Allen S. Whiting, Former. Director of the Office of Research and Analysis for the Far East, Department of State, 1962-66. The author examines the struggle of China to achieve political and economic modernization. Forthcoming

All volumes in this series approx. 128 pages, paperbound $\$ 1.95$, cloth $\$ 4.95$.

\section{FOUNDATIONS OF PUBLIC ADMINISTRATION}

Edited by Wallace S. Sayre

The Foundations of Public Administration Series explores recent developments in the field including the lineage between public administration and the political system, the sociological and social-psychological aspects of public administration, and the attempts to develop cross-cultural concepts of administration.

FOR 1967 PUBLICATION:

The Politics of Administration, by Wallace S. Sayre, Columbia University

The Politics of Bureaucracy, by Francis E. Rourke, The Johns Hopkins University 
PUblished title

Public Administration: A Comparative Perspective, by Ferrel Heady, University of New Mexico. 1966

FOR FUTURE PUBLICATION

The Administration of National Economic Policy, by Harvey Mansfield, Columbia University

National Security: Policy and Administration (author to be announced)

The volumes in the series are in a paperbound format of $6^{\prime \prime} \times 9^{\prime \prime}$, approx. 128 pp., each volume $\$ 1.95$

\section{THE CONTEMPORARY POLITICAL THEORY SERIES}

Edited by David Easton

This new series in political science is devoted to empirically oriented theory. The primary objective is to serve as in impulse in the direction of further elaboration and enrichment of theoretical thinking.

FOR 1967 PUBLICATION:

Sociological Analysis and Politics: The Theories of Talcott Parsons, William C. Mitchell, University of Oregon. Although Parsons has become one of the most controversial sociologists of his time, the author claims his importance is not limited to sociologists alone. Mitchell provides a detailed study of Parsons' writings synthesizing them from a political perspective. January 1967, 240 pp., cloth $\$ 5.95$

PUBLISHED TITLES IN THE SERIES:

A Framework for Political Analysis, edited by David Easton, University of Chicago. 1966,143 pp., cloth $\$ 5.95$

Varieties of Political Theory, edited by David Easton, University of Chicago. 1966,192 pp., cloth $\$ 5.25$

FOR FUTURE PUBLICATION

International Theory, by Arthur L. Burns, Australian National University

MOdern THEORY OF EQUality, by Wendell Bell, Yale University

Modern Theory of Representation, by John C. Wahlke, University of lowa

Toward A Theory of Political Competition, by Heinz Eulau, Stanford University

InTERNATIONAL RELATIONS TheORy, by J. David Singer, University of Michigan

\section{OUTSTANDING BOOKS TO BE PUBLISHED IN 1967}

Today's Isms; Communism, Fascism, Capitalism, Socialism, 5th Edition, 1967 by William Ebenstein, University of California, Santa Barbara

The new 5th Edition of this classic study offers an up-to-date overview of the world's major political systems: Communism, Fascism, Capitalism, and Socialism. The basic approach treats these four important Isms as ways of life rather than as specific governmental, economic or social institutions.

March 1967, Approx. 272 pp., paperbound \$3.75

California Government and Politics, 4th Edition, 1967 by Winston W. Crouch, University of California, Los Angeles; Dean E. McHenry, University of California, Santa Cruz; John C. Bollens, University of California, Los Angeles; Stanley Scott, University of California, Berkeley

Four noted authorities whose combined experience includes teaching, research, and public service over many years provide an inside view of the politics and problems of the most populous state in the nation. The emphasis is on current issues and political techniques with proper attention to the day-by-day operations of state and local governments. March 1967, approx. 336 pp., paperbound $\$ 3.75$

An Introduction To Political Analysis, 4th Edition, 1967 by Robert E. Lane, Yale University; James D. Barber, Yale University; Fred I. Greenstein, Wesleyan University.

This revised edition presents concrete case studies of government in action, which focus attention on significant political concepts and issues. The volume stresses the student's own role in developing and testing generalizations about political behavior and appraising political processes and policies. March 1967, approx. $385 \mathrm{pp}$., paperbound $\$ 5.50$

Foreign Policy IN World Politics, 3rd Edition, 1967 Edited by Roy C. Macridis, Brandeis University 
Introducing the student to the problems of foreign policy in the context of existing world relations, the Third Edition focuses upon ten contemporary national states and probes the factors that determine their foreign policy. The attitudes, purposes, and motivations which are peculiar to each of these nations, as well as the national characteristics which they have in common with other nations, are examined in relation to the mutual political and economic interests common to all nations. Each chapter is written by a specialist on the background, temperament, and foreign policy of the nation discussed. April 1967, approx. 416 pp., paperbound $\$ 4.95$

The Government of The United States, by Ernest B. Fincher, Montclair State College

By using a quantity of factual information and anecdotal material the author underscores the dynamic character of American government and its relationship to the lives of ordinary citizens. The text covers in depth major aspects of national government such as political parties; interest groups, federal courts, and the presidency. January $1967,320 \mathrm{pp}$., paperbound $\$ 3.95$

Foreign Policy of The American People, 3rd Edition, 1967 by Charles O. Lerche, Jr.

The completely revised Third Edition bases its analysis upon the role of the "American people" in foreign affairs and examines the responses of the United States to the challenges of an unstable world. Emphasis is on the broader scope of considerations in national foreign policy and Soviet-American confrontations. January 1967,387 pp., $\$ 8.25$

Parties and the Governmental System: A Book of Readings, by Garold W. Thumm, Bates College, and Edward Janosik, University of Pennsylvania Composed of articles from scholarly journals and excerpts from important political science books, Parties and the Governmental System is a new and refreshing anthology that brings together selected materials dealing with the theory and practice of political parties-their nature and functions, their organization, their operations, and their ecology. May 1967, approx. 320 pp., paperbound $\$ 3.95$

Function and Policies of American Government, 3rd Edition, 1967 by J. W. Peltason, University of California, Irvine, and James M. Burns. Williams College Functions and Policies of American Government describes comprehensively what American government does and what its specific policies are. It discusses governmental policies, functions, and programs against a background of history and politics, which encompass events as recent as those in the Johnson administration. May 1967, approx. 464 pp., \$6.95

InTernational Politics, by K. J. Holsti, University of British Columbia Offers an integrated framework for analyzing the behavior of states, with emphasis on the systemic and domestic sources of external political goals, the bargaining methods used to achieve or defend objectives and interests, restraints on policies, and behavior and procedures conducive to the resolution of international conflicts. May 1967 , approx. 512 pp., $\$ 8.95$

Issues of Political Development, by Charles W. Anderson, Fred R. von der Mehden, Crawford Young, all of the University of Wisconsin

Here is one of the first genuinely comparative studies of the politics of developing nations. The common and distinctive experiences of the emerging nations of Africa, Asia, and Latin America are examined to show both common features and subtle shades of differences in the way these nations confront critical problems of political development. The authors explore such crucial themes as national integration, political order, and the problems of finding a workable idealogy of development. May 1967 , approx. 280 pp., paperbound $\$ 3.95$

\section{For approval copies, write:}

Box 903

Prentice-Hall

Englewood Cliffs

New Jersey 07632

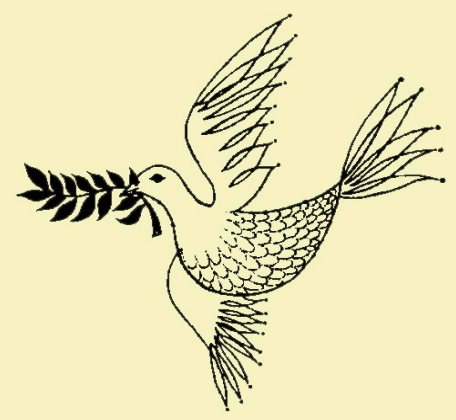




\section{Proceedings of the \\ Virginia State Convention of 1861 February 13 to May 1}

Edited by George H. Reese

Head, Historical Publications Division, Virginia State Library

liv, 3155 pp. $6 \% \times 9 \%, 4$ vols., Boxed. $\$ 60.00$ the set

Proceedings of the Virginia State Convention of 1861: February 13 to May 1 brings together for the first time the complete texts of Virginia's historic "secession debates."

An authoritative introduction is included along with a synoptical guide of each day's proceedings-a valuable aid in following the progress of the sessions.

To all intents and purposes, Virginia's official withdrawal from the Federal Union on May 23, 1861, was a mere formality. The actual drama took place at the Convention, and all the turmoil and excitement of that crucial decision has been recaptured in these speeches. These four volumes provide the standard text for one of the most important legislative sessions ever held in this country.

Published by the Virginia State Library

Distributed by the University Press of Virginia

\section{Annexation in Virginia}

The Use of the Judicial Process

for Readjusting

City-County Boundaries

Chester W. Bain

Olin D. Johnston, Professor of Political Science,

University of South Carolina

xiv, 258 pp., $6 \times 9 \%$, index, L.C. 66-12468, $\$ 6.00$

Unique to the state of Virginia is complete reliance on judicial procedure for readjusting municipal boundaries. Chester W. Bain, in Annexation in Virginia, gives a critical analysis of this procedure and its applicability to other states.

The General Assembly of Virginia adopted a statute in 1904 transferring the responsibility for annexation from the political realm to the judicial and established a special court of law presided over by judges selected from the state's judicial system to handle the cases. Mr. Bain closely examines legislative history from 1904 to June 30,1965 , with attention to the forces that have influenced the adoption and amendment of the statute. The issues and questions that have arisen under the statute are presented, and the way in which the courts have decided the issues is evaluated. Annexation in Virginia was published for the Institute of Government of the University of Virginia.

\section{University Press of Virginia Charlottesville}




\section{OUTSTANDING MCGRAW-HILL TEXTS IN POLLTICAL SCIENCE}

\section{STATE AND LOCAL GOVERNMENT, Second Edition}

By Charles R. Adrian, University of Californio, Riverside. Available Winter.

MeGraw-Hill Series in Political Science.

\section{INTRODUCTION TO POLITICAL SCIENCE, Second Edition}

By Carlton Clymer Rodee, Totton James Anderson, and Carl Quimby Christol, all of University of Southern California. Available Spring. McGraw-Hill Series in Political Science.

\section{VOICE OF THE PEOPLE: Second Edition}

Edited by Reo M. Christenson, Miami Universify Robert O. McWilliams, Eastern Michigan University. Available Spring.

McGraw-Hill Series in Political Science.

Elements of American Government, Seventh Edition. 512 pages. $\$ 7.95$

The American Federal Government, Ninth Edition. Coming this spring.

The American System of Government, Ninth Edition. Coming this spring.

All three by John H. Ferguson, The Pennsylvania State University; and Dean E. McHenry, University of California at Santa Cruz.

\section{THE DYNAMICS OF MODERN GOVERNMENT}

By Eugene J. Meehan, Brandeis University; John P. Roche, Brandeis University; and Murray $\mathbf{S .}$ Stedman, Jr., Trinity College. 450 pages, $\$ 7.50$

\section{THE AMERICAN POLITICAL PROCESS}

By Charles R. Adrian, University of California, Riverside; and Charles Press, Michigan State Universify. 756 pages. $\$ 7.95$

\section{FOUNDATIONS OF AMERICAN GOVERN- MENT AND POLITICAL SCIENCE}

Joseph P. Harris, Consulting Editor

Revisions and additions have been made to keep this series up to date and to enlarge its scope, but its purpose remains the same as it was on first publication: To provide a group of relatively shorf treatises dealing with major aspects of government in modern society.

Andrew Hacker: The Study of Polltics: The Western Tradifion and American Origins

C. Herman Pritchett: The American Constituflonal System, Second Edition

Hugh A. Bone and Austin Ranney: Polities and Voters, Second Edition

Rowland Egger: The President of the Unifed Stafes

Joseph P. Harris: Congress and the Legislative Process

John J. Corson and Joseph P. Harris: Publle Administration in Modern Society

Charles O. Lerche, Jr.: America in World Affairs, Second Edition

Charles R. Adrian: Governing Our fifty Stafes and Their Communities, Second Edition

H. Frank Way, Jr.: Liberty in the Balence: Current Issues in Civil Lberties, Second Edition

AMERICAN POLITICS AND THE PARTY SYSTEM, Third Edition

By Hugh A. Bone, University of Washington. McGraw-Hill Series in Political Science. 700 pages, $\$ 8.95$

THE GOVERNMENT AND POLITICS OF CALIFORNIA, Third Edition

By Henry A. Turner, University of California, Santa Barbara; and John A. Vieg, Pomona College and Claremont Graduate School, Calif.

UNITED STATES FOREIGN POLICY: Perspectives and Analysis

By William P. Gerberding, University of California, Los Angeles.

McGraw-Hill Series in Political Science. 400 pages. $\$ 7.95$

\section{MCGRAW-HILL BOOK COMPANY}




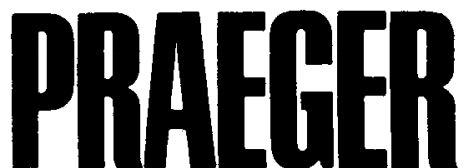

New Paperbacks

in International

Relations

\section{IN PURSUIT OF \\ WORLD ORDER \\ U.S. Foreign Policy and International Organizations \\ Revised Edition}

By RICHARD N. GARDNER. Introduction by Harlan Cleveland. Now thoroughly updated: "An admirable guide to the intentions and hopes of the United States in the United Nations. . . . Lucid, readable, and authoritative." ARThur M. SCHLESINGER, in The New Republic. 281 pp. U-616 $\$ 2.25$

\section{THE EVOLUTION OF INTERNATIONAL ORGANIZATIONS}

Edited by EVAN LUARD. Ten distinguished authorities-among them, Sydney D. Bailey, Geoffrey Goodwin, Inis L. Claude, Jr., and Andrew Shonfield-trace the history, structure, and functions of the most important international bodies, including the U.N. and the World Bank. "The approach is fresh and unique."-Library Journal 342 pp. notes, bibliog., index. U-620/ $\$ 2.95$

\section{THE STRUGGLE FOR PEACE}

By LEONARD BEATON. The Well Known Consultant at The Institute for Strategic Studies, London, explores what the world's leaders have learned, or failed to learn, from the Cuban missile crisis, from Vietnam, and from each of the other crises of recent years. 118 pp. P-220/\$1.45

\section{WORLD POLITICS IN AN AGE OF REVOLUTION}

By JOHN W. SPANIER. "A text that is outstanding for its clarity, its style, and its comprehensiveness in dealing with the revolutionary events of our time. The author confronts major problems directly; in doing so, he provides the student with information he can bring to bear upon the issues of politics and the problems of theory that the author so sharply identifies."-KENNETH N. Waltz, Professor of Politics, Brandeis University. A Praeger Paperbound Text. 488 pp. bibliog., index. $\$ 3.95$

\section{THE COMMUNIST STATES}

\section{AND THE WEST}

Edited by ADAM BROMKE and PHILIP E. UREN. "This collection of twelve essays . . . describes and evaluates change in the Communist world in terms of East-West relations. . . . It will succeed admirably in revealing 'something of the new international reality' to the interested layman and the beginning student of foreign affairs."- $-\mathrm{Li}$ brary Journal. 253 pp. U-619/\$2.25

\section{THE HARD AND}

\section{BITTER PEACE}

\section{World Politics Since 1945}

By G. F. HUDSON. An illuminating study of the international scene from the end of World War II to the present, by the author of The Far East in World Politics and Europe and China. With a chronology of significant events in great power relations, 1945-65. 319 pp. bibliog., index. U-594/\$2.50

\section{FREDERICK A. PRAEGER, Publishers}

111 Fourth Avenue,

New York, N.Y. 10003

Please mention The AMerican Polttcat. Scrence Review when writing to advertisers 


\section{Presenting}

Van Nostrand Political Science Series. General Editor: Franklin L. Burdette.

\section{CONDUCT OF AMERICAN DIPLOMACY}

Third Edition

By Elmer Plischke, University of Maryland. Just Published.

The Third Edition of this widely acclaimed reference and text for Foreign Service candidates and students of American diplomacy has been completely revised and updated.

THE SOVIET CRUCIBLE, The Soviet System in Theory and Practice, Third Edition

Edited with introductory notes by Samuel Hendel, The City College of the City University of New York. Available Summer, 1967. Approximately 600 pages; about $\$ 4.95$ (paper).

Soviet society-its premises, achievements, failures, and prospects-is examined in this rich and skillfully balanced collection of writings.

\section{DIMENSIONS OF AMERICAN FOREIGN POLICY Readings and Documents}

Edited with chapter introductions by Martin C. Needler, University of New Mexico. 1966; 384 pages; $\$ 4.75$ (paper).

United States foreign policy of the present, the re cent past and the future, is the theme of this timely collection of readings.

\section{LIBERALISM VERSUS CONSERVATISM: The Continuing Debate in American Government: Key Readings}

By Willmoore Kendall, University of Dallas; and George W. Carey, Georgetown University. 1966; 464 pages; $\$ 4.50$ (paper).

This collection of dynamic readings by key thinkers offers a balanced presentation of conservative and liberal thinking on the American political system for today's student of American government.

\section{EUROPEAN POLITICAL INSTITUTIONS}

\section{Second Edition}

By William G. Andrews, Tufts University. 1966; 608 pages; $\$ 4.95$ (paper).

"This is an excellent and well selected collection of articles, speeches, and documents. It makes a most useful supplement to the usual textbook of comparative European government. I intend to prescribe the new edition as I did the old."-E. Feit, University of Massachusetts.

POLITICAL AND ECONOMIC CHANGE IN LATIN AMERICA: The Governing of Restless Nations

By Charles W. Anderson, University of Wisconsin. lust Published in paperback.

Here is a dynamic approach to the study of Latin American politics, focusing on the most important problem of that continent-the struggle for economic and social change.

\section{ADMINISTRATIVE QUESTIONS AND POLITICAL ANSWERS}

Edited by Claude E. Hawley. The City University of New York, and Ruth E. Weintraub, The City University of New York (Hunter College). 1966; 616 pages; $\$ 5.95$ (paper).

The text is comprised of outstanding articles that focus on the major trends and ideas in the field over the past twenty-five years and indicates how ad. ministrative agencies have adapted to their political environment.

\section{New Perspectives in Political Science General Editor: William G. Andrews} MARXISM: A Re-Examination 13

By Irving M. Zeitlin, Indiana University. Available May, 1967. Approximately 200 pages, about $\$ 1.95$. In this four-part study of the social and political theory of Karl Marx, the author explains the nondogmatic character of Marx's work, what constitutes nondogmatic maxism, and how the theory is affecting and will affect social science research.

\section{THE DEMOCRATIC EXPERIMENT 14} American Political Theory, Volume I

By Neal Riemer, University of Wisconsin-Milwaukee. Available May, 1967. Approximately 256 pages, about $\$ 2.45$.

The creative spirit of our forefathers coupled with their rare ability to function as philosopher-statesmen helped to guide the creative democratic experiment in reconciling liberty and authority in a large state is the main theme of this study.

\section{CIVIL LIBERTIES IN EUROPE 15}

Four Case Studies

Edited by Ronald Bunn, Louisiana State University; and William G. Andrews, Tufts University. Contributors: Michael Gehlen, Jerome King, Geoffrey Marshall, Ronald Bunn. Available May, 1967. Approximately 256 pages, about $\$ 2.45$.

Civil liberties problems in Great Britain, France, West Germany, and the Soviet Union are described and analyzed in this casebook by four key specialists.

Send for your on-approval copies. Write to the College Department,
120 Alexander Street

Princeton, New Jersey 08540 


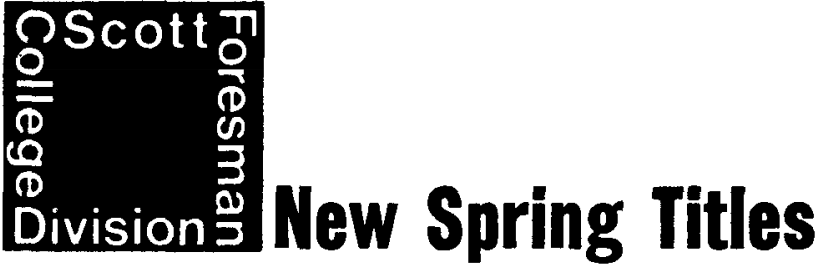

\section{THE SUPREME COURT AND CONSTITUTIONAL RIGHTS}

\section{Readings in Constitutional Law}

\section{MARTIN M. ShaPIRo, University of California, Irvine}

This substantive collection of readings, designed to survey the most important current cases, doctrines, and issues in the area of constitutional law, focuses on what the Supreme Court has done and ought to do about current issues. Topics examined in depth include freedom of speech, freedom of religion, reapportionment, Negro civil rights, expatriation, and the rights of accused persons. While a certain amount of necessary technical discourse is included, most of the materials deal with important general questions of public policy. The editor has written chapter introductions and selection headnotes and has added a brief section on research methods and problems at the end. Ready in late Spring, approx. 256 pages, softbound, prob. $\$ 3.75$

\section{CONTEMPORARY CIVILIZATION}

\section{Issue 4}

James Findlay, DePauw University

A collection of essays on the world in the mid-sixties, this book can be used as a basic text in a current affairs course, as one element in a social science survey, or as supplementary material in a political science course such as American Institutions or International Relations. While the selections are completely different from those appearing in the previous editions of the book, they represent a wide range of institutions and areas of special interest. Instead of separate chapters on the Soviet Union and Communist China, a single essay on the Communist world as a whole is included. The new essay on Africa considers the Middle East, and a new chapter on religion increases the coverage given to contemporary socio-cultural areas. Two of the authors, Vera Dean and Holland Hunter, appeared in Contemporary Civilization: Issue 3; the remaining eleven contributors are new and include Soviet expert Donald Zagoria, sociologist Robert Nesbit, and critic Robert Ellman. The essays are generally political in emphasis but include consideration of social problems, science, religion, and the arts. A preface by Henry Steele Commager and a separate section of readings from current journals and magazines provide additional perspective. Issue 4 contains four maps, 50 photographs, and a chronological chart of significant events since 1945 which has been updated and keyed more directly to the essays. Ready in April, approx. 320 pages, softbound, prob. $\$ 3.50$

\section{SCOTT, FORESMAN AND COMPANY College Division}
Glenview, Illinois
Atlanta
Dallas
Palo Alto
Oakland, N.J. 


\section{The POLITICS of ESCALATION in VIETNAM \\ By FRANZ SCHURMANN, PETER DALE SCOTT, REGINALD ZELNIK}

"A most important and revealing history, and a clear demonstration of what is wrong with the strategy of escalation."-John Kenneth Galbraith. "THE POLITICS OF ESCALATION IN viETNAM is probably the best single investment anyone can make in the literature on Vietnam. . . . It is a work which I would like to see seriously and thoughtfully debated by Administration advocates."-Bernard B. Fall, New York Review of Books.

A Fawcett Premier paperback book, 160 pp., 60\%

\section{VIETM.M. History, Documents and Opinions on a Major World Crisis \\ Edited, with an Introduction by MARVIN E. GETTLEMAN}

Here are materials on which statesmen and policymakers rely and which will enable the reader to understand our involvements. Selected writings of historians, statesmen, and journalists which illustrate the key events and major epochs in the evolution of Indochina. A rich collection of basic documents-some available nowhere else in this country-including statements of governments, international agreements, and monitored radio broadcasts.

A Fawcett Crest paperback book, 448 pp., $95 \not$

\section{INTERNATIONAL COMMUNISM IN THE ERA OF LENIN, A Documentary History} BY HELMUT GRUBER

This volume provides a concise and stimulating narrative framework into which the texts of the most significant doctrinal statements, manifestoes, analyses, tactical decisions, and polemics of the movement have been interwoven. The contents highlight the outstanding events in communism's heroic period and illuminate the growth of the national communist parties against the background of the developing Communist International.

A Fawcett Premier paperback book, about 512 pages, May $95 \not$

Education Dept., Desk FD

\section{FAWCETT PUBLICATIONS, INC.}

67 West 44 St., New York, N.Y. 10036

Please mention The Amkrican Political Scrence Review when writing to adwertisers 


\section{Peaceful Coexistence}

International Law in the Building of Communism

\section{By Lt. Col. Bernard A. Ramundo}

This study explores the Soviet position on basic questions of international law and contemporary international legal problems. The purpose throughout is twofold: to determine the manner in which the Soviets utilize international law to support policy objectives, and to decide whether, and to what degree, the Soviet approach to international law differs from that of other countries. The Soviet Union, Dr. Ramundo contends, has outgrown its earlier role as an "outlaw State," and now manifests an acute sensitivity to the need to demonstrate legal propriety in international relations. The law of peaceful coexistence has been devised to fill this need in the interest of the realization of Soviet foreign policy objectives.

$\$ 6.95$

\section{Northern California's Water Industry}

The Comparative Efficiency of Public Enterprise in Developing a Scarce Natural Resource

By Joe S. Bain, Richard E. Caves, and Julius Margolis

The provision of fresh water is a highly complex undertaking, involving independent local public agencies, regular departments or bureaus of government, private companies, and individuals who have their own wells. Most previous studies have emphasized the activities of state or federal water agencies; this book analyzes in great detail the whole operation of water supply in a large area-the "water industry" of Northern California. Although this study deals specifically with Northern California, its "industry study" approach might well serve as a pattern for other areas.

Published for Resources for the Future, Inc.

$\$ 15.00$

\section{NAACP}

A History of the National Association for the Advancement of Colored People, Vol. 1, 1909-1920

\section{By Charles Flint Kellogg}

This is Volume I of a projected two volume series which is likely to become the definitive history of the NAACP. Professor Kellogg, who has drawn heavily on the previously unavailable Spingarn and Du Bois papers, traces the development of the NAACP from its founding in 1909 by Oswald Garrison Villard, W. E. Du Bois, and the Committee of Forty to its acceptance by Negroes as the most effective organization in the United States working for political and social equality.

$\$ 8.75$

THE JOHNS HOPKINS PRESS

Baltimore, Maryland 21218 


\section{Available This Spring}

\section{ON CAPITOL HILL: Studies in the Legislative Process JOHN BIBBY, University of Wisconsin-Milwaukee ROGER DAVIDSON, Dartmouth College}

Based entirely on the original research of the authors, here is a series of descriptive and analytical studies designed specifically to illustrate and illuminate certain aspects of Congressional operations and the environment in which the legislator works. Each of the studies is complete within itself, and can be adapted to a variety of teaching techniques or approaches.

January 1967

288 pp.

$\$ 3.25$

\section{THE AMERICAN POLITICAL DICTIONARY, SeCOnd Edition}

\section{JACK C. PLANO and MILTON GREENBERG,} both of Western Michigan University

Over 1100 terms are carefully defined in a paragraph setting forth both the historical and current significance of each. Every entry has been revised to some degree in this new edition, and seventy-five new lexical terms have been added. With few exceptions, each chapter has four sections, the first and longest section in each case being an alphabetical listing of terms. Cross references are given for similar or closely related entries. March 1967 416 pp.

$\$ 4.50$ paper (tent.)

\section{GOVERNMENT AND POLITICS IN LATIN AMERICA: A Reader}

PETER G. SNOW, State University of Iowa

This distinctive collection of readings - taken from the writings of political scientists, as well as historians, journalists, sociologists, anthropologists, and economists-provides a review of the cultural background, governmental and political systems, and major political issues of present-day Latin America.

March 1967

560 pp.

$\$ 8.50$ (tent.)

\section{UNDERSTANDING THE CONSTITUTION, Fourth Edition}

By the late EDWIN S. CORWIN, and

JACK W. PELTASON, University of California, Irvine

This book provides a clause-by-clause explanation of the articles and amendments of the Constitution and a discussion of the practical significance of its most important provisions as they are interpreted and applied today.

March 1967

192 pp.

$\$ 2.95$ paper (tent.)

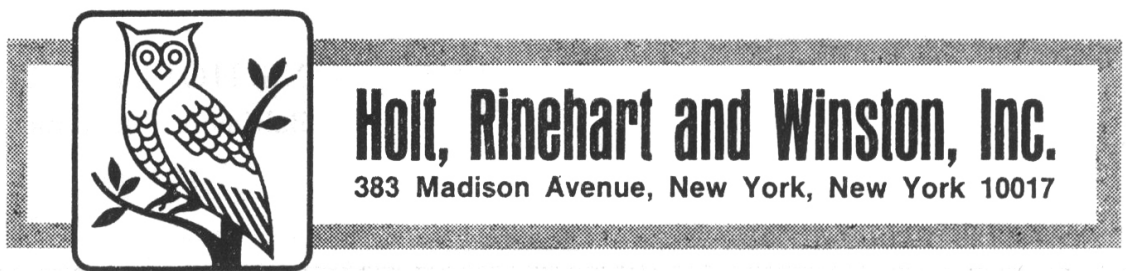

Please mention The American Political Science Review when writing to advertisers 


\section{An Atlas of Russian History}

\section{Eleven Centuries of Changing Borders}

by Allen F. Chew

This atlas, which combines thorough scholarship with the most practical features for use, will become an indispensable supplement to texts on Russian affairs. Large in format $\left(81 / 4 \times 10^{3} / 4\right.$ inches $)$, with $\mathrm{c}$ spiral binding which allows the maps to lie flat, the book contains thirty-four maps which show how Russia's boundaries have changed from the formation of Kievan Rus in the ninth century to the most recent revisions resulting from World War II. Each map is accompanied by concise, descriptive text.

\section{Poverty amid Affluence}

edited by Leo Fishman

Written by eminent social scientists and public leaders, the eleven papers presented here were originally delivered in May 1965 at the West Virginia University Conference on Poverty amid Affluence. "Must reading. "- -Publishers' Weekly.

\section{Greek Political Reaction to American and Nato Influences}

by Theodore A. Couloumbis

Traces recent controversies that have entwined internal and international politics in Greece, and finds evidence to support the hypothesis that U.S. aid and influence facilitated the Conservative hegemony from 1952 to 1963.

$\$ 7.50$

\section{The Trauma of Decolinization}

The Dutch and West New Guinea

by Arend Lijphart

In demonstrating that the motives behind Dutch reluctance to let go of West New Guinea were subjective and psychological, the author challenges economic explanations of colonialism. Yale Studies in Political Science, 17.

\section{New Yale Paperbounds}

\section{Arms and Influence}

\section{by Thomas C. Schelling}

"This is a brilliant and hardheoded book. It will frighten those who prefer not to dwell on the unthinkable and infuriate those who have taken refuge in stereotypes and moral attitudinizing. "-Gordon A. Croig, New York Times Book Review.

$\$ 1.95$ (eloth $\$ 7.50$ )

\section{The Lawmakers}

Recruitment and Adaptation to Legislative Life

by James David Barber

"Clearly one of the most significant studies of American politics written since the advent of behovioral studies in political science." -Western Political Quarterly.

\section{Children and Politics \\ by Fred I. Greenstein}

"The first book-length empirical treatment of the political socialization of American elementary school children."-American Political Science Review.

\section{available through your bookstore \\ Yale University Press Y $\mathbf{A}$ \\ New Haven and London $\mathrm{L} \cdot \mathbf{E}$ \\ in Canada: McGill University Press}




\section{INDEX TO ADVERTISERS}

Allyn \& Bacon, Inc. .......................... 262, 263

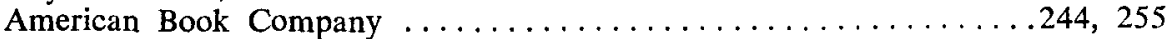

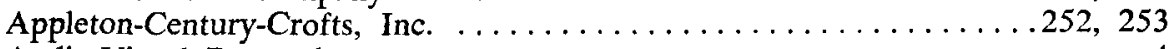

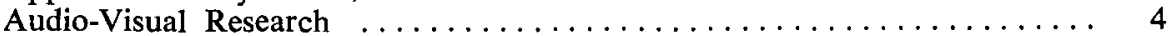

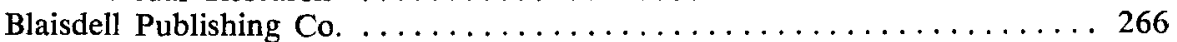

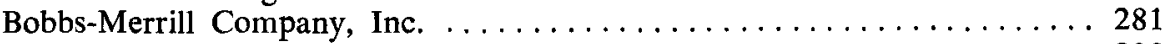

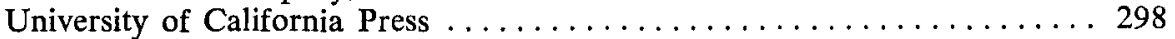

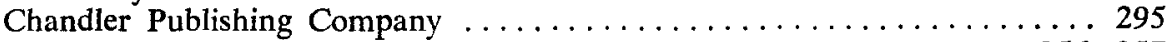

University of Chicago Press $\ldots \ldots \ldots \ldots \ldots \ldots \ldots \ldots \ldots \ldots \ldots \ldots \ldots \ldots \ldots \ldots \ldots \ldots \ldots \ldots, 257$

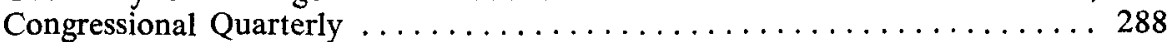

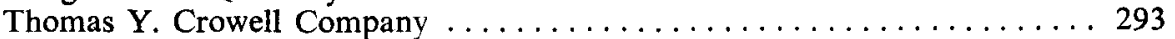

Dodd, Mead \& Company . . . . . . . . . . . . . . . . . . . . . . . 292

Dorsey Press ........................... 272, 273

Doubleday \& Company, Inc. . . . . . . . . . . . . . . . . 245, 289

Exposition Press ................................ 291

Fawcett Publications, Inc. ........................ 308

Free Press .......................... 274, 275, 276

Harcourt, Brace \& World, Inc. . . . . . . . . . . . . . . . 278, 279, 288

Harper \& Row $\ldots \ldots \ldots \ldots \ldots \ldots \ldots \ldots \ldots \ldots \ldots \ldots \ldots, 248,249,250$

Harvard University Press . . . . . . . . . . . . . . . . . . . . 290

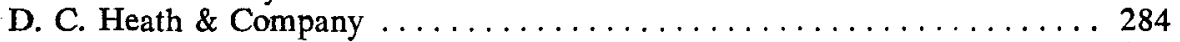

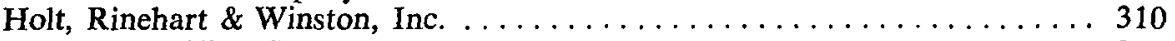

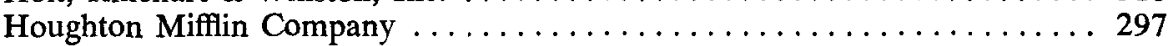

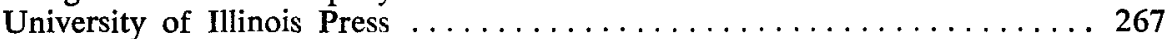

Johns Hopkins Press ............................. 309

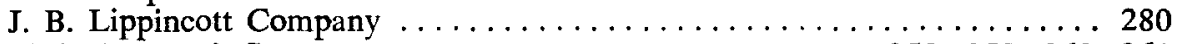

Little, Brown \& Company $\ldots \ldots \ldots \ldots \ldots \ldots \ldots \ldots \ldots 258,259,260,261$

McGraw-Hill Book Company ........................ 304

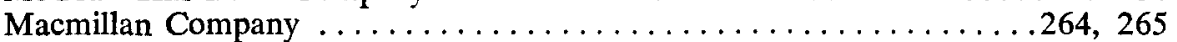

Northwestern University Press . . . . . . . . . . . . . . . . . . . 296

Oxford University Press $\ldots \ldots \ldots \ldots \ldots \ldots \ldots \ldots \ldots . \ldots \ldots, 241,242,243$

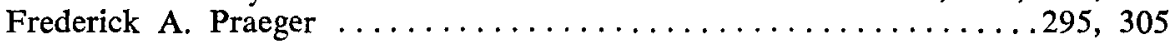

Prentice-Hall, Inc. $\ldots \ldots \ldots \ldots \ldots \ldots \ldots \ldots \ldots 246,299,300,301,302$

Princeton University Press $\ldots \ldots \ldots \ldots \ldots \ldots \ldots \ldots \ldots \ldots \ldots \ldots \ldots$ Cover II

Rand McNally \& Company $\ldots \ldots \ldots \ldots \ldots \ldots \ldots 238,239,251$, Cover IV

Random House .......................268, 269, 270, 271

Ronald Press ............................... 277

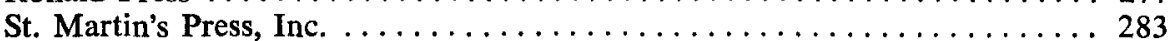

Science Research Associates ......................... 285

Scott, Foresman \& Company . . . . . . . . . . . . . . . . . . . . . 307

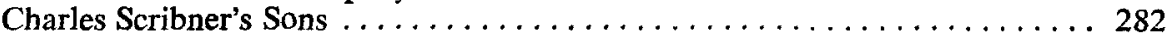

Teachers Insurance \& Annuity Association . . . . . . . . . . . . . . 247

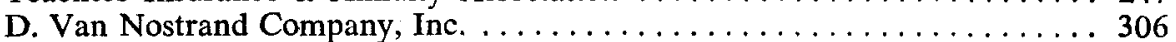

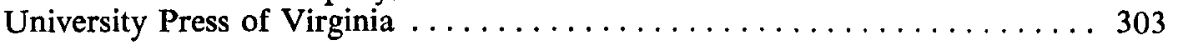

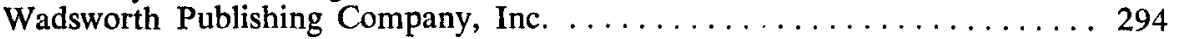

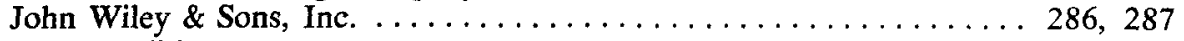

World Politics ................................ 291

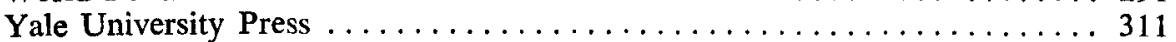




\title{
INTERNATIONAL POLITICAL SCIENCE ASSOCIATION
}

\section{SEVENTI WORLD CONGRESS}

\author{
BRUSSELS, SEPTEMBER 18-23, 1967
}

\section{Information on the Congress, Travel Grants, and Charter Flights}

\section{General Information}

The International Political Science Association will meet September 18-23, 1967 in Brussels. There will be both a series of meetings on general topics and a series of specialist meetings; attendance at the latter will be by invitation or by application to the scholar in charge. Registration fee for members of IPSA will be $\$ 10.00$; for others $\$ 15.00$.

\section{Travel Grants}

The American Political Science Association has a grant from the National Science Foundation to assist Americans who are participating in or attending the Congress. Funds are limited and applications will be reviewed and grants made by an Association committee.

\section{Charter Flights}

The Association has arranged for two charter flights at reduced rates. Flight 1 will be on Pan American leaving September 15 and returning September 25. Round trip cost: $\$ 331.00$. Flight 2 will be on Pan American leaving September 9 and returning September 24. Round trip cost, $\$ 250.00$ plus $\$ 70.00$ worth of ground accommodations arranged through the Association.

Full information about the Congress, travel grants and charter flights can be obtained from:

\section{THE AMERICAN POLITICAL SCIENCE ASSOCIATION}

1527 New Hampshire Avenue, N.W.

WASHINGTON, D.C. 20036 


\section{PLURALIST DEMOCRACY \\ IN THE UNITED STATES: \\ Conflict and Consent}

\section{ROBERT A. DAHL • Yale University}

This basic textbook traces the development of American democracy and introduces the student to an original political philosophy of American government.

The text is organized around an historical analysis of conflict and consensus within a pluralist democracy. After describing the formation of the American pluralist democracy, Dahl discusses the political institutions and how they contribute to that democracy, examines American pluralist democracy as it functions in conflict, and finally assesses the influence which an individual can have on a pluralist democracy.

Throughout the text Dahl integrates theories and findings of behaviorally oriented studies wherever relevant, refers to traditional sources, and quotes extensively from classical writings. His analysis of the behavior of a pluralist democracy in the presence of conflict gives an innovative dimension to the book. His development of this facet is supported by case studies and theoretical analyses.

In his smoothly flowing writing style, Dahl adopts the mood and tone of a scholar talking directly with his readers. His use of personal references and frequent asides promotes a rapport and involvement on the part of the student. Dahl encourages personal analysis by offering penetrating questions about the formation, principles, and applications of pluralist democracy.

Part I. How and Why a Pluralist Democracy Emerged on the American Continent

1. Conflict and Consent

2. A Republic-If You Can Keep It

3. The Silent Revolution: Proof of the Impossible

Part II. How American Political Institutions Evolved; How They Contribute to Pluralist Democracy

4. The Presidency

5. The Congress

6. The Supreme Court

7. The Other Ninety Thousand Governments

8. The Political Parties: Origins and Characteristics

9. Political Parties: Contributions to Democracy

Part III. How a Pluralist Democracy Behaves in the Midst of Conflict and Cleavages

10. Conflict and Conciliation

11. Comprehensive Change and Severe Conflict

12. Political Polarization and Civil War

13. The Conditions of Moderate Conflict

14. Overlapping Cleavages-Low Polarization

Part IV. How Political Activists Can Exert Influence in a Pluralist Democracy

15. Influencing the Conduct of Government

16. Four Cases of Political Action

17. Alternative Strategies for Political Activists

RAND MCNALLY \& COMPANY

The College Department • Box 7600 - Chicago, Illinois 60680 